\title{
Solvated fullerenes, a new class of carbon materials suitable for
}

\author{
high-pressure studies: A review \\ Lin Wang ${ }^{1,2,3, *}$ \\ ${ }^{1}$ HPSynC, Geophysical Laboratory, Carnegie Institution of Washington, Argonne, IL 60439, USA \\ ${ }^{2}$ State Key Laboratory of Superhard Materials, Jilin University, Changchun 130012, China \\ ${ }^{3}$ Center for High Pressure Science and Technology Advanced Research, 1690 Cailun Rd, Pudong \\ District, Shanghai 201203, China \\ *E-mail addresses: wanglin@ hpstar.ac.cn or 1wang@carnegiescience.edu
}

\begin{abstract}
As the list of known carbon compounds grows longer, solvated fullerenes have become a more important class of carbon materials. Their general properties and methods of synthesis have both attracted considerable attention. The study of the behavior of these compounds under high-pressure conditions has revealed several new phenomena that have never been observed in pure fullerene. This article is a review of all recent progress in this field.
\end{abstract}

Keywords:
A. Fullerenes
C. High pressure
D. Crystal structure
D. Phase transitions

\section{Introduction}

Carbon became one of the most attractive elements in the periodic table during the 1980's. It attracted a great deal of research effort in material science, chemistry, and condensed matter physics. Several new carbon allotropes, including fullerenes $\left(\mathrm{C}_{60}\right.$, $\mathrm{C}_{70}$, etc.), carbon nanotubes, and graphene have been discovered and subjected to study in the past few decades. [1-4] Within the carbon family, fullerenes have very unique closed-cage structure and can be treated as zero dimensional materials, which have many fascinating properties. The family includes $\mathrm{C}_{20}, \mathrm{C}_{36}, \mathrm{C}_{60}, \mathrm{C}_{70}$, and other compounds. [5-9] They have a wide range of properties and considerable potential in applications such as energy storage and solar cells. [10-13]

Pressure is a very important parameter in tuning materials' properties. The distance between atoms, crystal structure, and electronic structure of the atoms can all be modified under high pressure. [14-17] High-pressure structural evaluations of $\mathrm{C}_{60}$ and $\mathrm{C}_{70}$ have been performed and the polymerization of $\mathrm{C}_{60}$ and $\mathrm{C}_{70}$ has been widely studied. [18-22] The fullerene molecules themselves are incompressible, but the intermolecular interactions are weak. The $\mathrm{C}=\mathrm{C}$ bonds also make it possible to generate polymerized phases. These characteristics of fullerenes yield a rich variety of phase transitions under compression conditions and across a wide range of temperatures. Several great reviews of this topic have been made. [18-21] 
The superconductive properties of alkali-doped fullerenes have made them a hot topic. [9, 23-25] The structural stability and superconducting transition temperatures of alkali-doped fullerenes have also been studied thoroughly. [24,25] The fact that fullerenes can generate solvates when they crystallize from solvents is of particular interest. [26-29] Many studies have focused on the growth and characterization of solvated fullerenes. [26-45] High-pressure studies on this kind of fullerene materials have been carried out by several groups. [46-57] High-pressure structural investigations were performed on solvated fullerenes and this family was found to behave very differently from pure and alkali-doped fullerenes. In 2012, Wang et al. discovered a novel long-range ordered material constructed from units of amorphous carbon clusters which was synthesized by compressing solvated fullerenes. [58] After the discovery, this topic has attracted more attentions and a great deal of progress has been made. To emphasize the importance of these materials, the following review of recent studies on solvated fullerenes and their properties, including phase transitions and polymerization under high-pressure conditions, was assembled. This review may interest more research groups in this field.

\section{Fullerenes}

Closed fullerenes were first predicted by Jones in 1966. [5, 59] He proposed large, hollow, closed-cage molecules constructed from sheet-like material. These could be used to counteract the considerable discontinuity between the density of gas and of the condensed phase. Later, he suggested that such a cage-shaped molecule could be fashioned out of graphite. [60] He also pointed out that exactly 12 pentagons are required to close a cage comprising only pentagons and hexagons. In 1985, Kroto et al. reported their experimental discovery of a 60-carbon cluster in the mass spectrum of laser-evaporated graphite. [1] Another cluster containing 70 carbon atoms was found to be the next most abundant peak in the mass spectrum. The authors proposed a closed-cage, truncated-icosahedral structure and named the molecule Buckminsterfullerene in honor of R. Buckminster Fuller who introduced geodesic structures in architecture. Figure 1 shows the structures of $\mathrm{C}_{60}$ and $\mathrm{C}_{70}$ molecules. They both show closed-cage structures. $\mathrm{C}_{60}$ contains 12 pentagons and 20 hexagons of carbon rings, and $\mathrm{C}_{70}$ contains 25 hexagons and 12 pentagons.
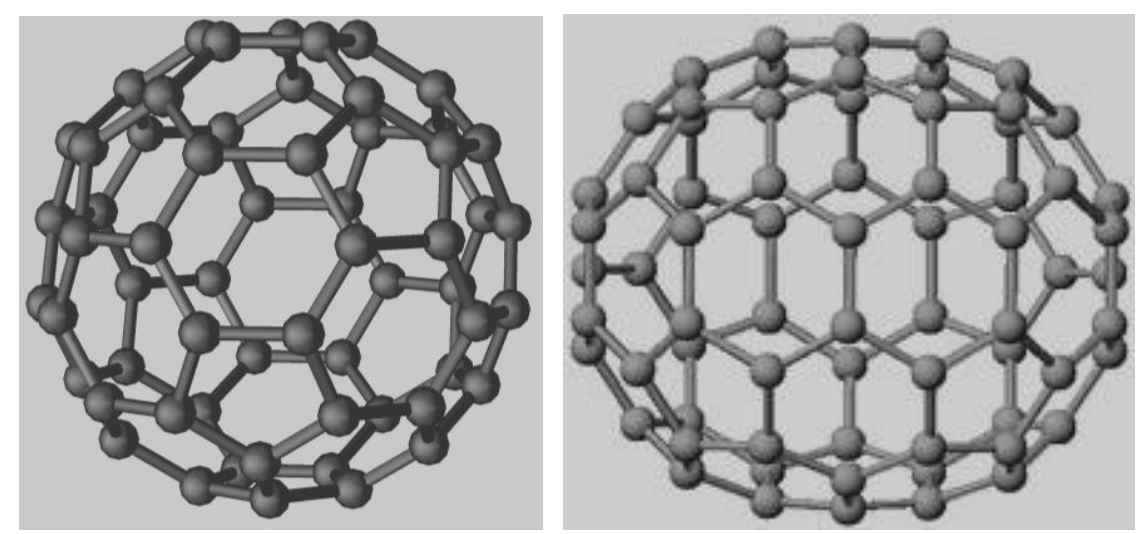

Figure 1. The structures of $\mathrm{C}_{60}$ and $\mathrm{C}_{70}$ molecules. 
In 1990, Kratschmer et al. found an efficient method of synthesizing $\mathrm{C}_{60}$ and $\mathrm{C}_{70}$ in gram quantities - by arcing graphite electrodes. [2] This gave rise to a burst of studies on these molecules, a renaissance in the study of the properties of fullerenes and carbon in different allotropes. [3,4]

\section{Fullerenes under high pressure}

Due to their super-strong covalent intramolecular C-C bonds, $\mathrm{C}_{60}$, the most common fullerene, has been predicted to have an extremely large bulk modulus of around 800-900 GPa for an individual molecule. [61, 62] This value is almost twice that of diamond (442 GPa), which is the hardest known material. [63] For this and several other reasons, high-pressure studies of fullerenes have drawn a lot of attentions since the 1990s. [58,64-70]

$\mathrm{C}_{60}$ molecules form a face-centered cubic (fcc) structure under ambient conditions. Under compression conditions, the crystal undergoes an orientation transition at around $0.4 \mathrm{GPa}$, causing the fcc structure to transforms into a simple cubic (sc) structure. $[18,65,71]$ The sc structure can persist at a pressure of $25 \mathrm{GPa}$. At higher pressure, $\mathrm{C}_{60}$ cages start to collapse and the crystalline structure becomes amorphous. $[65,72]$ This pressure-induced amorphization is irreversible.

Because the formation of bonds between neighboring $\mathrm{C}_{60}$ molecules is a thermally activated process, the polymerization reaction is very slow at room temperature and molecular $\mathrm{C}_{60}$ is therefore stable at high pressures and temperatures below 350-400 K. [18-20] However, many studies have provided evidences suggesting that $\mathrm{C}_{60}$ polymerizes at pressure over $4 \mathrm{GPa}$ at room temperature. $[73,74]$ Upon heating at high pressure, $\mathrm{C}_{60}$ has a variety of polymerized phases. [18-20] Figure 2 shows a pressure-temperature phase diagram of $\mathrm{C}_{60}$.

Under high-pressure conditions ( 1.5 GPa) and at high temperatures (373-473 K), $\mathrm{C}_{60}$ dimerizes, when the crystal structure is still in sc.[75] Long linear clusters or chains are believed to form and a phase transition from sc to an orthorhombic phase occurs at higher pressures ( 0.7- 9GPa) and temperatures (<700K). [76-78] As shown in figure $3 \mathrm{~A}$, the chains are along the (110) direction.

At higher temperatures (>700 K), the number of intermolecular bonds increases and complete two-dimensional (2D) polymerization phases have been observed at the pressure range of $\sim 1$ to $\sim 9 \mathrm{GPa}$. As shown in figure $3 \mathrm{~B}$ and $\mathrm{C}$, the $2 \mathrm{D}$ sheets of linked molecules can form in two ways. One is that the nearest neighbors in the (100) plane are bound together into squares forming a tetragonal lattice. In another formation the molecules in the close-packed (111) plane form a trigonal polymer sheet and generate a rhombohedral lattice. [18,20] The new structures are stable at a wide range of pressure-temperature conditions including atmospheric pressure. [79] 
Three-dimensional (3D) polymerization becomes highly probable at higher pressures ( $>8 \mathrm{GPa}$ ) upon heating. $[18,20]$ The profile analysis of the diffractions obtained for $\mathrm{C}_{60}$ samples quenched from $13 \mathrm{GPa}$ and $670-820 \mathrm{~K}$ yielded proof of the formation of $3 \mathrm{D}$ polymerized $\mathrm{C}_{60}$ phase. From the simulations of possible structures it was concluded that the most probable structure of $3 \mathrm{D}$ polymerized $\mathrm{C}_{60}$ synthesized at the conditions is a body-centered orthorhombic Immm structure. [80,81] The authors further suggested that the formation of this structure starts with 1D chains by $(2+2)$ cycloaddition, followed by $2 \mathrm{D}$ polymerization by four-sided rings. At higher temperatures, further bonds form between $2 \mathrm{D}$ layers by a $(3+3)$ cycloaddition reaction resulting in a $3 \mathrm{D}$ polymerization $\mathrm{C}_{60}$ phase. Marques and coworkers synthesized 3D $\mathrm{C}_{60}$ polymer at $13 \mathrm{GPa}$ and $800-820 \mathrm{~K}$, and studied its anisotropic property. [82,83]] Interestingly, they found an elliptical Debye-Scherrer pattern due to strong anisotropic pressure effect. It has been reported that $3 \mathrm{D} \mathrm{C}_{60}$ show interesting mechanical and thermal properties, although the results reported by different groups are still controversial.

Submitting the material to further pressure can cause the structure become random or amorphous and the cages are still intact and form the basic building blocks of the structure. [84] As the pressure increases even further (>12 GPa) at high temperatures $(>1100 \mathrm{~K})$, the cages start to collapse and form a second amorphous phase containing carbon fragments. [85,86] At temperatures near $2000 \mathrm{~K}$, diamonds can form when at pressures higher than $10 \mathrm{GPa}$. [18-20]

$\mathrm{C}_{70}$ is much more complicated and less studied than $\mathrm{C}_{60}$. Unlike $\mathrm{C}_{60}$, which has a pure fcc structure at room temperature, all real $\mathrm{C}_{70}$ crystals contain mixtures of several structural phases mainly of fcc and hexagonal closed packed (hcp) structures because of the molecular anisotropy. There are many degrees of freedom. The structure of $\mathrm{C}_{70}$ under high-pressure conditions was studied by Wasa et al. using Raman scattering up to $51 \mathrm{GPa}$ at room temperature. [87] A majority of the intramolecular vibrational modes disappeared and only one broad band associated with amorphous carbon was found to persist as pressures above $12 \mathrm{GPa}$, suggesting an occurrence of pressure-induced amorphization. The transition was shown to be complete by around $18 \mathrm{GPa}$. The amorphous phase was irreversible at pressures above $35 \mathrm{GPa}$. Earlier high pressure $\mathrm{X}$-ray diffraction studies of $\mathrm{C}_{70}$ nanorods showed pressure-induced amorphization to take place at pressures of $\sim 23 \mathrm{GPa}$, indicating a strong effect in nanoscale fullerenes crystal. [66] Very recently, $\mathrm{C}_{70}$ molecules were found to remain intact at pressures of up to $43 \mathrm{GPa}$, suggesting an even stronger size effect in fullerenes of smaller size. [70]

Like $\mathrm{C}_{60}, \mathrm{C}_{70}$ polymerizes at elevated temperatures under high-pressure. Figure 4 shows a pressure-temperature phase diagram of $\mathrm{C}_{70}$. $[18,20]$ It is found that the reaction diagram of $\mathrm{C}_{70}$ shows some general features with that of $\mathrm{C}_{60}$, but contains much fewer phases. At relatively low pressures, $\mathrm{C}_{70}$ dimerizes. Lebedkin and coworkers synthesized $\mathrm{C}_{70}$ dimer at $1 \mathrm{GPa}$ and $473 \mathrm{~K}$. [88] At higher pressure (2GPa) 
and higher temperature $(500-600 \mathrm{~K})$, crystals of $\mathrm{C}_{70}$ containing zig-zag chains are formed. [89] As shown in Figure 4, a rhombohedral, two-dimensional polymeric phase can be formed over a wide range of temperature and pressure. At pressures above $9 \mathrm{GPa}$ tetragonal, three-dimensional polymers are produced. [90]

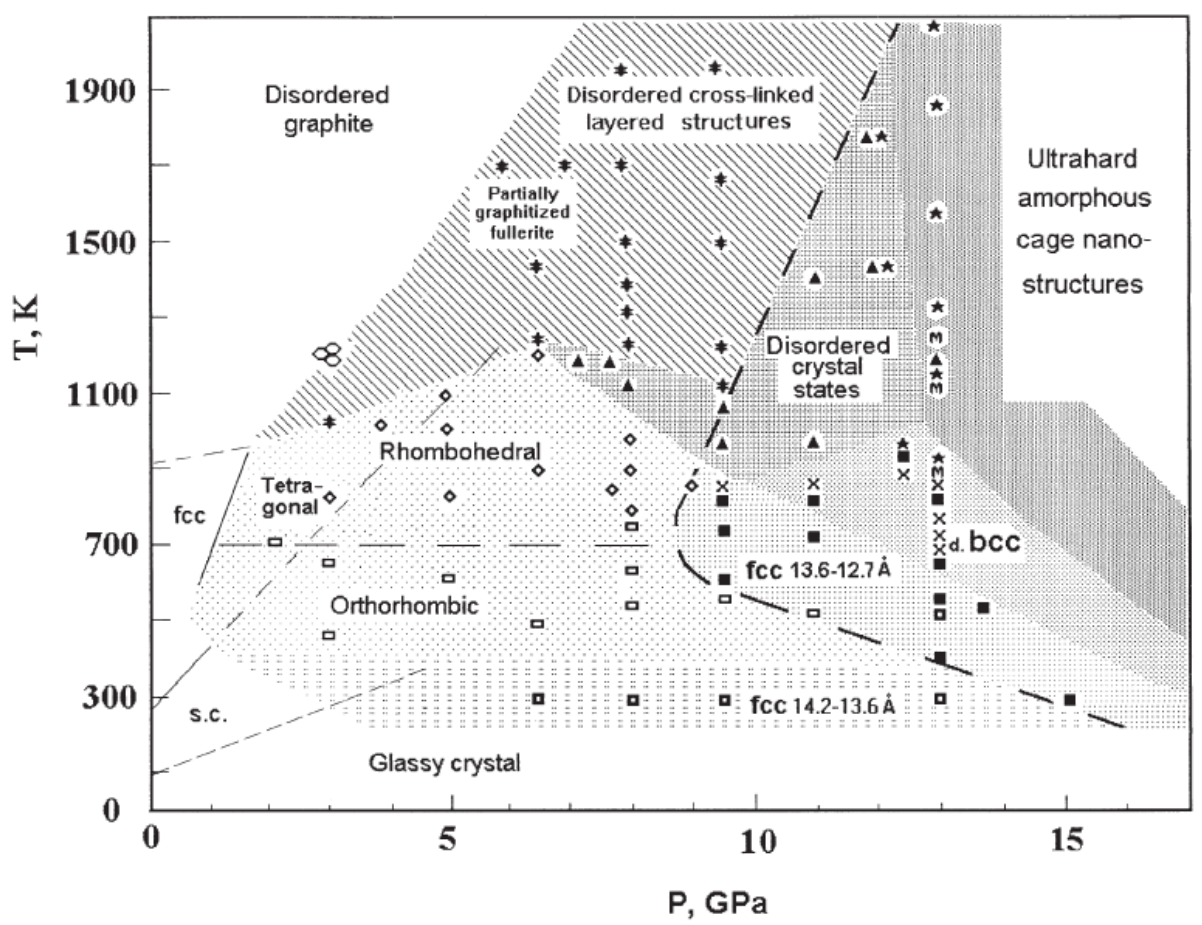

Figure 2. Phase diagram of $\mathrm{C}_{60}$ showing the structural phases obtained under the pressure-temperature conditions shown. (Reprinted with permission from B. Sundqvist [20])

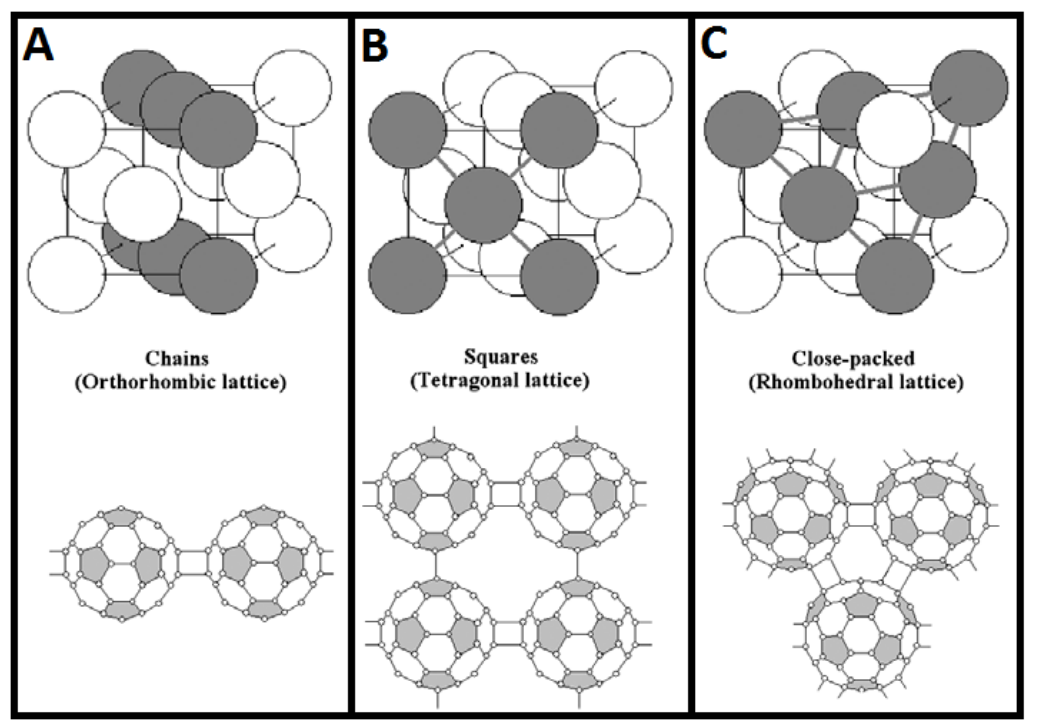

Figure 3. Basic structures of the three low-dimensional phases of $\mathrm{C}_{60}$. (Reprinted with permission from B. Sundqvist [20]) 


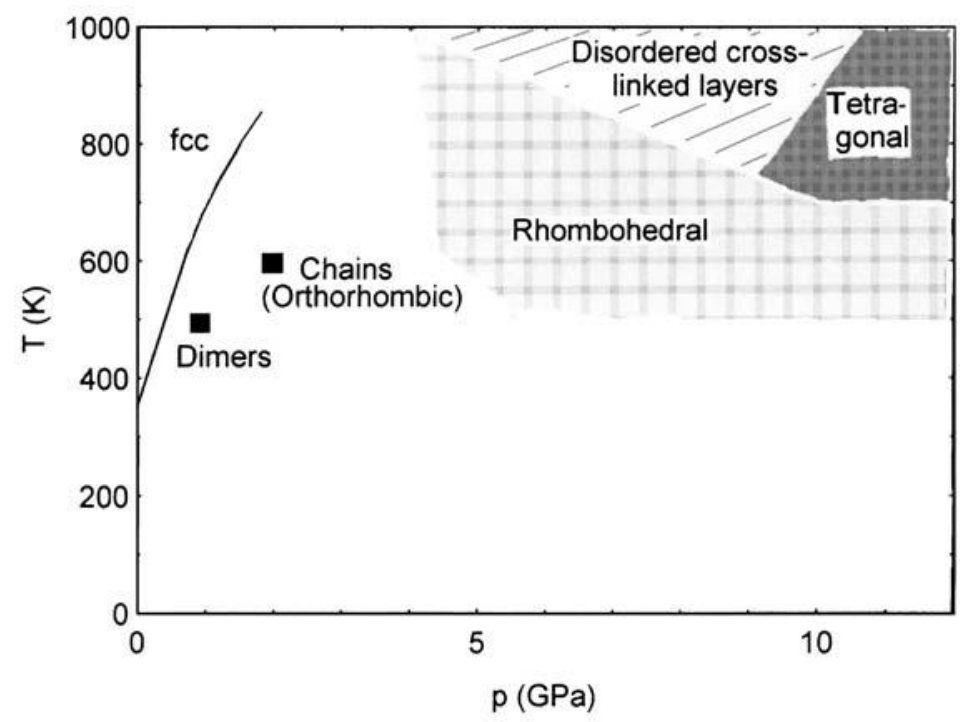

Figure 4. Pressure-temperature phase diagram of $\mathrm{C}_{70}$. (Reprinted with permission from B. Sundqvist [20])

The band structures of fullerenes have been studied under high-pressure conditions. $\mathrm{C}_{60}$ is a semiconductor with a band gap of $1.7 \mathrm{eV}$. It was expected that $\mathrm{C}_{60}$ becomes metallic under high pressure. The band gap of $\mathrm{C}_{60}$ under high-pressure conditions was measured using optical absorption spectroscopy. [72] The absorption edge shifts to lower energy as pressure increasing. The absorption edge shift was reported to be $-0.05 \mathrm{eV} / \mathrm{GPa}$ by Moshary et al., suggesting that metallization could occur by $33 \mathrm{GPa}$. [72] However, the molecules collapse at pressures of $25 \mathrm{GPa}$ and render metallization of pure fullerite inaccessible. The resistivity of fullerenes under high pressure has also been measured by several other research groups. No metallization has been found. The resistivity was found to increase during the amorphization transition of $\mathrm{C}_{60}$. [68]

\section{Solvated fullerenes}

Fullerenes are soluble in small amounts in many solvents including aromatics, such as toluene, xylene, and benzene, and others such as carbon disulfide. The solubility of fullerenes in many solvents has been determined. Table 1 shows solubility of $\mathrm{C}_{60}$ and $\mathrm{C}_{70}$ in some solvents. Their solubility varies significantly in different solvents. [91]

The solubility of fullerenes shows an unusual behavior in many solvents due to the relatively strong interactions between fullerenes and solvents, which causes the formation of solvate phases. [92] For example, $\mathrm{C}_{60}$ shows maximum solubility in benzene at about $313 \mathrm{~K}$. Crystallization from benzene solution at temperatures below maximum results in formation of triclinic solid solvate with four benzene molecules $\mathrm{C}_{60} \cdot 4 \mathrm{C}_{6} \mathrm{H}_{6}$ which is unstable in air. $[35,36,45]$ The preparation and characterization of solvated fullerenes have been widely studied. [26-45] Many fullerene solvates have been observed and make this group of materials an important class of fullerenes. In this section, the research status of fullerenes solvates is briefly reviewed.

Table 1 . The solubility of $\mathrm{C}_{60}$ and $\mathrm{C}_{70}$ in some solvents. [91] 


\begin{tabular}{|c|c|c|}
\hline Solvent & $\mathrm{C}_{60}$ & $\mathbf{C}_{70}$ \\
\hline 1-chloronaphthalene & $51 \mathrm{mg} / \mathrm{mL}$ & \\
\hline 1-methylnaphthalene & $33 \mathrm{mg} / \mathrm{mL}$ & \\
\hline 1,2-dichlorobenzene & $24 \mathrm{mg} / \mathrm{mL}$ & $36.2 \mathrm{mg} / \mathrm{mL}$ \\
\hline 1,2,4-trimethylbenzene & $18 \mathrm{mg} / \mathrm{mL}$ & \\
\hline tetrahydronaphthalene & $16 \mathrm{mg} / \mathrm{mL}$ & \\
\hline carbon disulfide & $8 \mathrm{mg} / \mathrm{mL}$ & $9.875 \mathrm{mg} / \mathrm{mL}$ \\
\hline 1,2,3-tribromopropane & $8 \mathrm{mg} / \mathrm{mL}$ & \\
\hline chlorobenzene & $7 \mathrm{mg} / \mathrm{mL}$ & \\
\hline xylene & $5 \mathrm{mg} / \mathrm{mL}$ & $3.985 \mathrm{mg} / \mathrm{mL}(\mathrm{p}$-xylene $)$ \\
\hline cumene & $4 \mathrm{mg} / \mathrm{mL}$ & \\
\hline toluene & $3 \mathrm{mg} / \mathrm{mL}$ & $1.406 \mathrm{mg} / \mathrm{mL}$ \\
\hline benzene & $1.5 \mathrm{mg} / \mathrm{mL}$ & $1.3 \mathrm{mg} / \mathrm{mL}$ \\
\hline carbon tetrachloride & $0.447 \mathrm{mg} / \mathrm{mL}$ & $0.121 \mathrm{mg} / \mathrm{mL}$ \\
\hline chloroform & $0.25 \mathrm{mg} / \mathrm{mL}$ & \\
\hline n-hexane & $0.046 \mathrm{mg} / \mathrm{mL}$ & $0.013 \mathrm{mg} / \mathrm{mL}$ \\
\hline acetonitrile & $0.004 \mathrm{mg} / \mathrm{mL}$ & \\
\hline methanol & $0.00004 \mathrm{mg} / \mathrm{mL}$ & \\
\hline pentane & $0.004 \mathrm{mg} / \mathrm{mL}$ & $0.002 \mathrm{mg} / \mathrm{mL}$ \\
\hline heptane & & $0.047 \mathrm{mg} / \mathrm{mL}$ \\
\hline octane & $0.025 \mathrm{mg} / \mathrm{mL}$ & $0.042 \mathrm{mg} / \mathrm{mL}$ \\
\hline decane & $0.070 \mathrm{mg} / \mathrm{mL}$ & $0.053 \mathrm{mg} / \mathrm{mL}$ \\
\hline dodecane & $0.091 \mathrm{mg} / \mathrm{mL}$ & $0.098 \mathrm{mg} / \mathrm{mL}$ \\
\hline acetone & & $0.0019 \mathrm{mg} / \mathrm{mL}$ \\
\hline isopropanol & & $0.0021 \mathrm{mg} / \mathrm{mL}$ \\
\hline dioxane & $0.0041 \mathrm{mg} / \mathrm{mL}$ & \\
\hline mesitylene & $0.997 \mathrm{mg} / \mathrm{mL}$ & $1.472 \mathrm{mg} / \mathrm{mL}$ \\
\hline dichloromethane & $0.254 \mathrm{mg} / \mathrm{mL}$ & $0.080 \mathrm{mg} / \mathrm{mL}$ \\
\hline
\end{tabular}

\subsection{Preparations of solvated fullerenes}

$\mathrm{C}_{60}$ and $\mathrm{C}_{70}$ fullerenes form solvates with almost all common solvents. Reported data for most of these solvates are summarized in Table 2. It can be seen that solvated 
fullerenes have been synthesized using a variety of solvents, including pentane, [37] hexane, [38] heptane, [39] benzene, [34-36] and $\mathrm{CS}_{2}$, [40,41] 1,1,2-trichloroethane $\left(\mathrm{CH}_{3} \mathrm{CCl}_{3}\right)$ [27]. In general solvated fullerenes can be synthesized by evaporating fullerene solutions. The earliest study on solvated fullerenes can be traced back to early 1990's. The solvate of $\mathrm{C}_{60}$ was realized soon after the report of large quantity synthesis of $\mathrm{C}_{60}$ using contact-arc vaporization of a graphite rod during extraction process. [93] The first report focused on solvated $\mathrm{C}_{60}$ and $\mathrm{C}_{70}$ was probably published by Fleming et al in July, 1991. [26] Pentane-solvated $\mathrm{C}_{60}$ and $\mathrm{C}_{70}$ were studied. The crystals appeared long and in ten-sided columns. Single crystal X-ray diffraction was performed. Results indicated that the crystals appeared in crystalline order with a twinned unit cell. In November 1991, Gorun et al. prepared cyclohexane-solvated $\mathrm{C}_{60}$ and $\mathrm{C}_{70}$ using slow cooling of supersaturated solutions of $\mathrm{C}_{60}$ and $\mathrm{C}_{70}$ mixtures for their structure studies. [42] However, solvates were found to lose their crystallinity when exposed to air because of solvent loss. Slow evaporation of benzene solution of $\mathrm{C}_{60}$ at around temperature of $50^{\circ} \mathrm{C}$ can produce benzene-solvated $\mathrm{C}_{60}$. The stoichiometric ratio of $\mathrm{C}_{60}$ to solvent was determined to be 1:4. From 1996-2007, the research group led by Tamarit has made considerable contributions to this field. $[27,32,33,38,97,98]$ Several fullerene solvates were synthesized and systematically characterized using X-ray diffraction (XRD), thermogravimetry (TGA), and differential scanning calorimetry (DSC). Aging studies of different solvates in the time scale of years were also performed. Korobov et al. studied the structures of 12 solvates (Table 2) of $\mathrm{C}_{60}$ and $\mathrm{C}_{70}$ with different structures and stoichiometry using XRD to establish a relationship between the X-ray and the thermodynamic data on solvated fullerene solvated crystals. [94] Solvates were found to be typical van-der-Waals complexes with negative excess volumes with packing coefficients from 0.72 to 0.78 . These are stable due to the formation of the bonds between fullerenes and solvent.

In synthesis, temperature plays an important role in the formation of solvated fullerenes. It affects stability and stoichiometry. For instance, $\mathrm{C}_{60} * m$-xylene remains stable at temperatures of up to $333 \mathrm{~K}$. [28,29] However, $\mathrm{C}_{60} *$ toluene only remains stables at low temperatures $(150 \mathrm{~K})$. [45] For $m-\mathrm{C}_{6} \mathrm{H}_{4} \mathrm{Br}_{2}$-solvated $\mathrm{C}_{60}$, the stoichiometric ratio changes at different temperatures. $\mathrm{C}_{60} * 2 m-\mathrm{C}_{6} \mathrm{H}_{4} \mathrm{Br}_{2}$ is only stable at low temperatures, and $\mathrm{C}_{60} * 2 / 3 m-\mathrm{C}_{6} \mathrm{H}_{4} \mathrm{Br}_{2}$ can be stable at room temperatures. [94]

Table 2. Summary of information of most of reported fullerenes solvates.

\begin{tabular}{|l|l|l|l|l|}
\hline Solvate & Crystal structure & $\begin{array}{l}\text { Stability in } \\
\text { air at } \\
\text { ambient T }\end{array}$ & $\begin{array}{l}\text { Characterization } \\
\text { technique used }\end{array}$ & references \\
\hline $\mathrm{C}_{60}{ }^{*} 1 m$-xylene & $\begin{array}{l}\text { Hcp, } \\
\text { a }=2.376 \mathrm{~nm}, \\
\mathrm{c}=1.008 \mathrm{~nm}\end{array}$ & stable & $\begin{array}{l}\text { XRD, Raman, IR, } \\
\text { TGA, TEM, SEM }\end{array}$ & Ref. 28 \\
& & & \\
\hline
\end{tabular}




\begin{tabular}{|c|c|c|c|c|}
\hline $\mathrm{C}_{60} * 4 \mathrm{C}_{6} \mathrm{H}_{6}$ & hcp & & XRD, Raman & $\begin{array}{l}\text { Ref. } 31, \\
34,45,94\end{array}$ \\
\hline $\mathrm{C}_{60} * 10 \mathrm{CCl}_{4}$ & Fcc a $=2.739 \mathrm{~nm}$ & stable & XRD & Ref. 95 \\
\hline $\mathrm{C}_{60} * \mathrm{C}_{6} \mathrm{H}_{5} \mathrm{CH}_{3}$ & monoclinic & Metastable & IR, Raman & \multirow{5}{*}{$\begin{array}{ll}\text { Ref. 31, } \\
45\end{array}$} \\
\hline $\mathrm{C}_{60} * 0.5 \mathrm{C}_{6} \mathrm{H}_{5} \mathrm{CH}_{3}$ & & & IR & \\
\hline $\mathrm{C}_{60} *$ decalin & hcp & & IR & \\
\hline $\begin{array}{l}\mathrm{C}_{60} * 6 n \text {-decane } \\
(210 \square \mathrm{C})\end{array}$ & & & IR & \\
\hline $\begin{array}{l}\mathrm{C}_{60} * 3 n \text {-decane } \\
(340 \square \mathrm{C})\end{array}$ & & & IR & \\
\hline $\mathrm{Cf}_{60} * 2 \mathrm{CHBr}_{3}$ & $\begin{array}{ll}\text { Hcp, } & \mathrm{a}=1.0226 \\
\mathrm{~nm}, & \mathrm{c}=1.0207 \\
\mathrm{~nm} & \end{array}$ & & XRD, TGA, NMR & Ref. 96 \\
\hline $\begin{array}{l}\mathrm{C}_{60} * 1,1,2 \text {-trichloroetha } \\
\text { ne }\end{array}$ & $\begin{array}{l}\text { Orthorhombic } \\
a=1.0164 \mathrm{~nm} \\
b=3.1390 \mathrm{~nm} \\
c=1.0130 \mathrm{~nm}\end{array}$ & Metastable & SEM, XRD, TGA & Ref. 27 \\
\hline $\mathrm{C}_{60} * n$-hexane & $\begin{array}{l}\text { Orthorhombic } \\
a=1.0249 \mathrm{~nm} \\
b=3.1308 \mathrm{~nm} \\
c=1.0164 \mathrm{~nm}\end{array}$ & stable & XRD, TGA, Raman & $\begin{array}{l}\text { Ref. } 31, \\
38\end{array}$ \\
\hline $\mathrm{C}_{60} * \mathrm{H}_{2} \mathrm{CCl}_{2}$ & $\begin{array}{l}\text { Cubic } \\
\mathrm{A}=2.3284 \mathrm{~nm}\end{array}$ & Unstable: & XRD, TGA & Ref. 97 \\
\hline $\mathrm{C}_{60} * 2$ Ferrocene & triclinic & & & Ref. 98 \\
\hline $\mathrm{C}_{60} * 12 \mathrm{BrCCl}_{3}$ & $\begin{array}{l}\text { Cubic } \\
A=2.7591 \mathrm{~nm}\end{array}$ & Unstable & \multirow[t]{2}{*}{ XRD, TGA, SEM } & \multirow[t]{2}{*}{ Ref. 99} \\
\hline $\mathrm{C}_{60} * 2 \mathrm{BrCCl}_{3}$ & $\begin{array}{l}\text { Hexagonal } \\
a=1.016 \mathrm{~nm} \\
b=1.089 \mathrm{~nm}\end{array}$ & Stable & & \\
\hline $\mathrm{C}_{60} * 2 / 3 n$-nonane & $\begin{array}{l}\text { Orthorhombic } \\
a=1.010 \mathrm{~nm} \\
b=1.019 \mathrm{~nm} \\
\mathrm{c}=4.871 \mathrm{~nm}\end{array}$ & Stable & SEM, XRD, TGA & Ref. 100 \\
\hline $\mathrm{C}_{60} * 2\left(\mathrm{CH}_{3}\right) \mathrm{CCl}_{3}$ & monoclinic & & & Ref. 33 \\
\hline $\mathrm{C}_{60} * 2 \mathrm{C}_{6} \mathrm{H}_{5} \mathrm{CH}_{3}$ & Monoclinic & & \multirow{7}{*}{$\begin{array}{l}\text { XRD, Differential } \\
\text { scanning } \\
\text { calorimetry (DSC) }\end{array}$} & \multirow[t]{7}{*}{ Ref. 94} \\
\hline $\mathrm{C}_{60} * \mathrm{C}_{6} \mathrm{H}_{5} \mathrm{CH}_{3}$ & monoclinic & & & \\
\hline $\mathrm{C}_{60} * 2 \mathrm{C}_{6} \mathrm{H}_{5} \mathrm{I}$ & monoclinic & & & \\
\hline $\mathrm{C}_{60} * 3 m-\mathrm{C}_{6} \mathrm{H}_{4} \mathrm{Br}_{2}$ & monoclinic & & & \\
\hline $\mathrm{C}_{60} * 2 m-\mathrm{C}_{6} \mathrm{H}_{4} \mathrm{Br}_{2}$ & monoclinic & & & \\
\hline $\mathrm{C}_{60} * \mathrm{C}_{6} \mathrm{H}_{5} \mathrm{Cl}$ & monoclinic & & & \\
\hline $\mathrm{C}_{60} * 2 o$-xylene & monoclinic & & & \\
\hline
\end{tabular}




\begin{tabular}{|c|c|c|c|c|}
\hline $\mathrm{C}_{60} * 2 / 3 m-\mathrm{C}_{6} \mathrm{H}_{4} \mathrm{Br}_{2}$ & hexagonal & & & \\
\hline $\mathrm{C}_{60} * 2 / 3 m$-xylene & hexagonal & & & \\
\hline $\mathrm{C}_{60} * 2 / 3 m-\mathrm{C}_{6} \mathrm{H}_{4} \mathrm{Cl}_{2}$ & hexagonal & & & \\
\hline $\mathrm{C}_{60} * 2 / 3 \mathrm{C}_{6} \mathrm{H}_{3}\left(\mathrm{CH}_{3}\right)_{3}$ & hexagonal & & & \\
\hline $\mathrm{C}_{70} * 2 o$-xylene & triclinic & & & \\
\hline $\mathrm{C}_{70} *$ Ferrocene & $\begin{array}{l}\text { monoclinic } \\
\mathrm{a}=2.938 \mathrm{~nm} \\
\mathrm{~b}=1.036 \mathrm{~nm} \\
\mathrm{c}=2.021 \mathrm{~nm}\end{array}$ & & & Ref. 101 \\
\hline $\mathrm{C}_{70} * 2$ mesitylene & $\begin{array}{l}\text { Cubic } \\
\mathrm{a}=1.04774 \mathrm{~nm}\end{array}$ & stable & $\begin{array}{l}\text { XRD, TGA, SEM, } \\
\text { Fluorescence }\end{array}$ & Ref. 102 \\
\hline $\mathrm{C}_{60} * \mathrm{CS}_{2}$ & monoclinic & & NMR & $\begin{array}{l}\text { Ref. 40, } \\
41\end{array}$ \\
\hline $\mathrm{C}_{60} * \mathrm{C}_{8} \mathrm{H}_{8}$ & $\begin{array}{l}\text { Fcc } \\
\mathrm{a}=1.474 \mathrm{~nm}\end{array}$ & stable & $\begin{array}{l}\text { XRD, TEM, Raman, } \\
\text { IR, TGA, and Mass } \\
\text { spectrometry, NMR }\end{array}$ & Ref. 103 \\
\hline $\mathrm{C}_{70} * \mathrm{C}_{8} \mathrm{H}_{8}$ & $\begin{array}{l}\text { Tetragonal } \\
\text { (Room } \\
\text { Temperature) } \\
\text { I4/mmm } \\
\text { FCC (at }>375 \mathrm{~K} \text { ) }\end{array}$ & stable & $\begin{array}{l}\text { XRD, TEM, Raman, } \\
\text { IR, TGA, and Mass } \\
\text { spectrometry, NMR }\end{array}$ & $\begin{array}{l}\text { Ref. 103, } \\
104\end{array}$ \\
\hline $\mathrm{C}_{60} * \mathrm{~S}_{16}$ & $\begin{array}{l}\text { Monoclinic } \\
a=20.867(4) \AA, \\
b=21.062(4) \AA, \\
c=10.508(2) \AA, \\
\beta=111.25(7)^{\circ}\end{array}$ & stable & XRD, Raman & Ref. 105 \\
\hline $\mathrm{C}_{60} *$ n-pentane & orthorhombic & & XRD & Ref37 \\
\hline $\mathrm{C}_{60} *$ heptane & $\begin{array}{l}\text { Hexagonal } \\
\mathrm{a}=1.000(4) \mathrm{nm} \\
\mathrm{b}=1.016(1) \mathrm{nm}\end{array}$ & stable & XRD, TGA, SEM & Ref39 \\
\hline $\mathrm{C}_{60} * \mathrm{TDAE}$ & $\begin{array}{l}\text { Monoclinic } \\
a=1.5849 \mathrm{~nm} \\
b=1.2987 \mathrm{~nm} \\
c=0.9965 \mathrm{~nm} \\
\beta=93.31^{\circ}\end{array}$ & unstable & $\begin{array}{l}\text { XRD, Magnetic } \\
\text { measurement, } \\
\text { Electron } \\
\text { resonance }\end{array}$ & Ref. 55 \\
\hline
\end{tabular}

The incorporation of guest molecules into the host $\mathrm{C}_{60}$ lattice changes its crystal structure. As shown in Table 2, there are at least five types of packing symmetry relevant to these materials. They include hexagonal, cubic, monoclinic, triclinic, and orthorhombic. The structure is dependent on both the solvent and stoichiometric ratio. For example, $\mathrm{C}_{60}$ crystals grown in cyclohexane crystallize in the cubic system, [42] $\mathrm{C}_{60}$ crystals with $\mathrm{CS}_{2}$ or n-pentane have orthorhombic structures, [41] and $\mathrm{C}_{60}$ 
solvates grown from benzene and $n$-heptane have a hexagonal lattice. [31]

$\mathrm{C}_{60} * 2 \mathrm{BrCCl}_{3}$ has a hexagonal lattice, however $\mathrm{C}_{60} * 12 \mathrm{BrCCl}_{3}$ is in cubic. [99] The solvents with symmetrical geometry and small size should be able to fit in the large octahedral voids of fullerene lattices and cause no change of the crystal structure. For example, $\mathrm{C}_{8} \mathrm{H}_{8}$, a cubic molecule, occupies the interstitial octahedral sites of $\mathrm{C}_{60}$ and forms $\mathrm{C}_{60} * \mathrm{C}_{8} \mathrm{H}_{8}$ with an fcc structure which is same as for the pure $\mathrm{C}_{60}$ crystals. When solvents have non-symmetric geometry or polar molecules, the solvated fullerenes can not stay in their mother structure in most of cases. The species of solvent and crystal structure can highly affect their high pressure polymerization behavior.

Solvate crystals of different shapes form from different solvents. Taking 1,1,2trichloroethane and bromotrichloromethane $\left(\mathrm{BrCCl}_{3}\right)$ as examples, the $\mathrm{C}_{60} 1: 1$ solvate formed with 1,1,2-trichloroethane showed a needlelike shape with a polyhedral cross section, but $\mathrm{C}_{60} * 2 \mathrm{BrCCl}_{3}$ showed interpenetrating hexagonal single crystals, indicating that the polymorphism of $\mathrm{C}_{60}$ is solvent-dependent. [32] Another interesting example is $\mathrm{m}$-xylene, which was used as a shape controller in synthesis of nanorods of $\mathrm{C}_{60}$. Single-crystalline $\mathrm{C}_{60} * 1 \mathrm{~m}$-xylene nanorods with a hexagonal structures were successfully synthesized by evaporating a $\mathrm{C}_{60}$ solution in $\mathrm{m}$-xylene at room temperature. The hexagonal structures change into cubic structures due to total loss of solvent at temperature over $333 \mathrm{~K}$. They produce pure $\mathrm{C}_{60}$ nanorods. The ratio of the length to the diameter of the nanorods can be controlled within a range of 10 to over 1000 for different applications. Figure 5 shows a SEM picture of as-grown $\mathrm{C}_{60} * 1 m$-xylene solvate nanorods. No changes in shape were observed during heating events, which involved loss of solvent. [28,29]

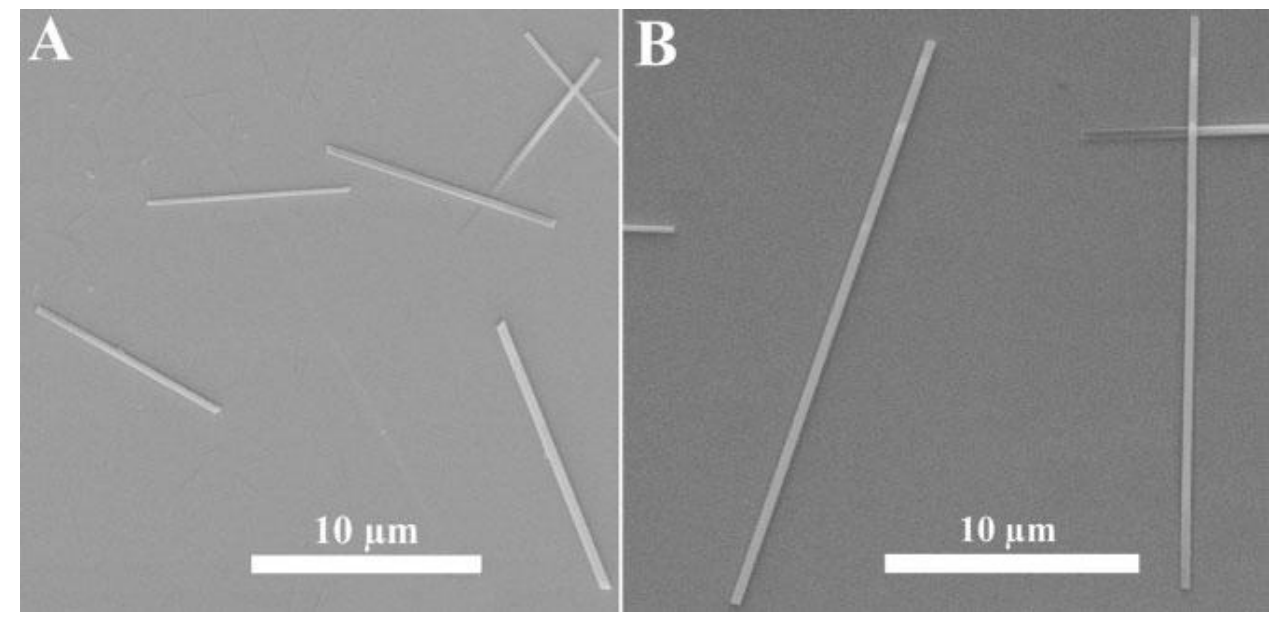

Figure 5. SEM images of as-grown $\mathrm{C}_{60} * 1 m$-xylene solvate nanorods. [28,29] (Reprinted with permission from Wang et al. [29])

\subsection{Physical properties of solvated fullerenes}

The properties of solvated fullerenes have also been studied. Guest molecules were also found to change the vibrational properties of the fullerene crystals and thus the 
Raman and IR (infrared absorption) spectra of $\mathrm{C}_{60}$. The Raman spectra of $\mathrm{C}_{60}$ solvates formed in solvents such as benzene and toluene showed new peaks not visible in the spectra of pristine $\mathrm{C}_{60}$, and other peaks shifted location. [31] Graja et al. reported that the guest molecules can hinder the rotation of $\mathrm{C}_{60}$ molecules which leads to a decrease of vibrational-rotational couplings. [44,45] However, the NMR measurements on $\mathrm{C}_{60} * 4$ benzene suggest that interactions between benzene and $\mathrm{C}_{60}$ molecules are very weak, and the rotation of $\mathrm{C}_{60}$ is not hindered. [35,106] It is therefore very interesting to study the solvent-dependent polymorphism and the properties of $\mathrm{C}_{60}$ solvates formed with various solvents.

In solvated $\mathrm{C}_{60}$, the orientational ordering transition was found to be smeared and shifted to lower temperatures. For example, the orientational transition shifted to $170 \mathrm{~K}$ in $\mathrm{C}_{60}: n$-hpentane and below $77 \mathrm{~K}$ in $\mathrm{C}_{60}: \mathrm{CS}_{2}$. $[37,41,45]$

The interactions between fullerenes and solvents reduce the icosahedral symmetry of fullerene molecules, making electronic transitions previously impossible in pristine fullerenes possible. This changes their optical properties. The photoluminescence (PL) of $\mathrm{C}_{60} * m$-xylene was studied by the present team. The PL intensity of the solvate was found to be about 2 orders of magnitude higher than those of pristine $\mathrm{C}_{60}$, as shown in figure 6 . The quantum yield of the solvate was found 1-2 orders of magnitude higher than $\mathrm{C}_{60}$ as well. The extra Raman peaks observed in the solvate suggest van-der-Waals interactions between the $\mathrm{C}_{60}$ molecules and the solvents, which reduces the symmetry of the $\mathrm{C}_{60}$ molecular and renders electric-dipole transitions that were impossible with pristine $\mathrm{C}_{60}$ due to high symmetry possible. [28] This phenomenon has also been observed in $\mathrm{C}_{70}$ solvates. [102]
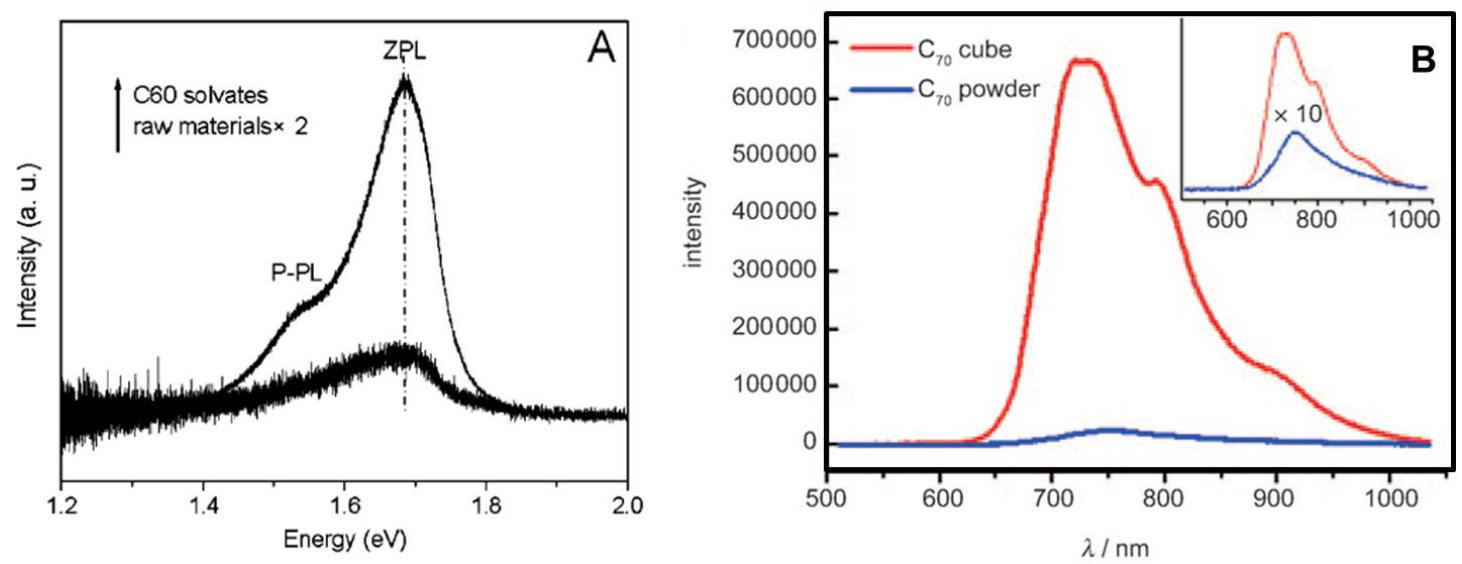

Figure 6. PL spectra of $\mathrm{C}_{60} * m$-xylene solvate and pristine $\mathrm{C}_{60}(\mathrm{~A})$, and $\mathrm{C}_{70} * 2$ mesitylene solvate and pristine $\mathrm{C}_{70}$ powder (B). (Adapted from [28] and [102])

\section{High-pressure studies of solvated fullerenes}


The high-pressure study of solvated fullerenes has attracted a lot of attentions. Several solvates of $\mathrm{C}_{60}$ and $\mathrm{C}_{70}$ with different solvent and structures have been systematically studied using techniques including XRD, Raman spectroscopy, inelastic X-ray scattering (IXS) spectroscopy, infrared absorption (IR) spectroscopy, high-resolution transmission electron microscopy (HRTEM), and theoretical calculations. Several new phenomena have been observed. [46,107-109] In this section, all recent studies and results will be briefly reviewed.

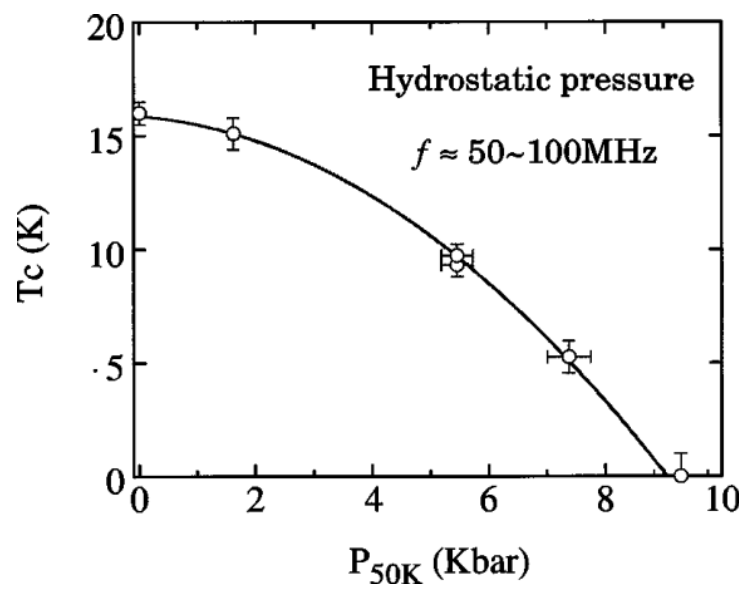

Figure 7. Tc versus P50K in $\mathrm{C}_{60} * \mathrm{TDAE}$. The solid curve indicates the theoretical predition with the data up to $7.4 \mathrm{kbar}$. (Reprinted with permission from Mizoguchi et al. [56])

$\mathrm{C}_{60} * \mathrm{TDAE}$ is an organic ferromagnetic material with high Curie temperature of $16.1 \mathrm{~K}$. Effects of hydrostatic pressure on $\mathrm{C}_{60} * \mathrm{TDAE}$ were investigated by electron spin resonance to reveal a mechanism of the ferromagnetism. It was found that the transition temperature $\mathrm{Tc}$ decreases with increasing pressure, reaching zero around 0.9 GPa. Figure 7 shows the pressure dependence of Tc. Above about $1 \mathrm{GPa}$ at $300 \mathrm{~K}$, it was found to transform to the one-dimensional polymerized phase. The new phase is stable even after pressure release. [55-57] The effects of uniaxial strain on Tc of $\mathrm{C}_{60} *$ TDAE single crystal were also studied. Tc as functions of pressure applied along b- and c-axis together with hydrostatic pressure is shown in Figure 8. It is clear that magnetic interactions are anisotropic. The b-axis strain enhances Tc up to $17.5 \mathrm{~K}$ under $4 \mathrm{kbar}$ of the applied pressure. The c-axis strain strongly suppresses the ferromagnetism. It is interesting that the b-axis strain also produces a fraction of the sample with the low Tc of about $10 \mathrm{~K}$. [57] 


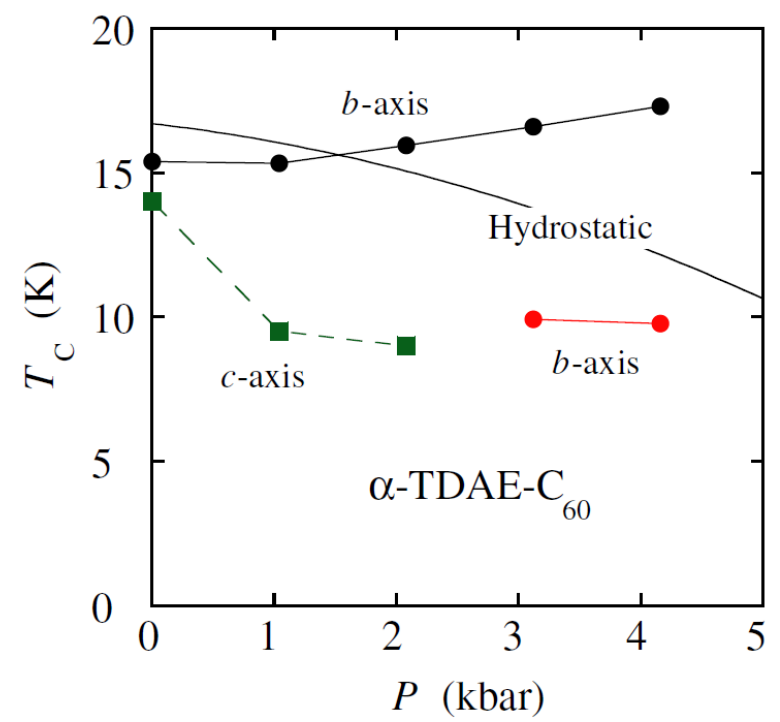

Figure 8. Tc variations caused by uniaxial strain along b-axis [110] and c-axis, together with by hydrostatic pressure [111] (Reprinted with permission from Mizoguchi et al. [57])

The rotor-stator compound $\mathrm{C}_{60} * \mathrm{C}_{8} \mathrm{H}_{8}$ was studied up to $10 \mathrm{GPa}$ at room temperature using infrared transmission. [46-51] It was found that kinks appeared in the pressure dependences of the frequencies of the molecular vibrations at around $0.8 \mathrm{GPa}$, suggesting the occurrence of an orientational ordering transition at room temperature. The qualitative features of the spectra at high pressure indicate a symmetry lowering of the fullerene molecules. The higher transition pressure in $\mathrm{C}_{60} * \mathrm{C}_{8} \mathrm{H}_{8}$ compared to $\mathrm{C}_{60}$ could be attributed to the expanded lattice. The cubane vibrational modes survive up to a higher pressure compared to the $\mathrm{C}_{60}$ modes, suggesting a considerable shielding of $\mathrm{C}_{8} \mathrm{H}_{8}$ molecules from pressure in the interball voids in the crystal. The pressure-temperature phase diagram of $\mathrm{C}_{60} * \mathrm{C}_{8} \mathrm{H}_{8}$ was systematically studied by Iwasiewicz-Wabnig et al. [46,47] They annealed $\mathrm{C}_{60} * \mathrm{C}_{8} \mathrm{H}_{8}$ at different temperatures in the range of $380-870 \mathrm{~K}$ under pressures up to $2 \mathrm{GPa}$. The treated samples were then investigated under ambient conditions using Raman spectroscopy and x-ray diffraction. $\mathrm{C}_{60} * \mathrm{C}_{8} \mathrm{H}_{8}$ was found to have at least five different phases depending on the treatment conditions, as shown in figure 9. [47] The pressure-temperature phase diagram is different from that of pure $\mathrm{C}_{60}$ suggesting the effect of $\mathrm{C}_{8} \mathrm{H}_{8}$ molecules. 


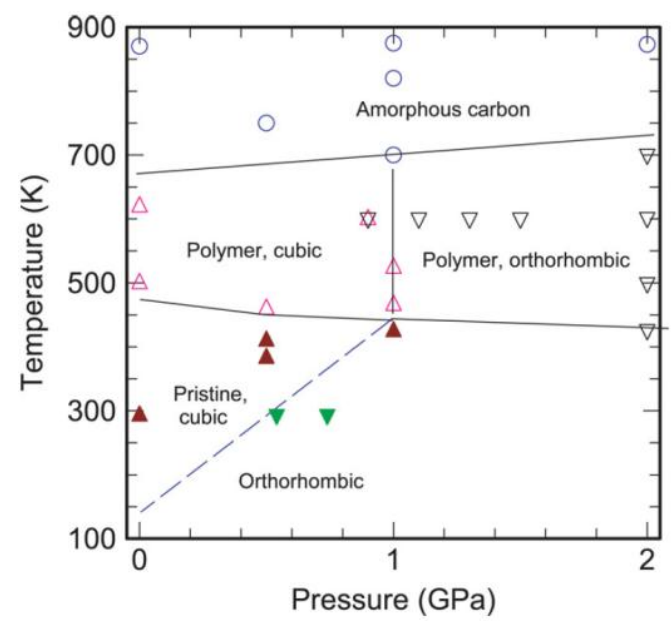

Figure 9. Pressure-temperature phase diagram of $\mathrm{C}_{60} * \mathrm{C}_{8} \mathrm{H}_{8}$. (Reprinted with permission from Iwasiewicz-Wabnig et al. [47])

$\mathrm{C}_{60} \mathrm{~S}_{16}$ is made of $\mathrm{C}_{60}$ and $\mathrm{S}_{8}$ rings. Talyzin et al. studied high pressure Raman of this material up to $12.4 \mathrm{GPa}$. [52] It was found that $\mathrm{C}_{60}$ molecules in this compound polymerize similar to the pure $\mathrm{C}_{60}$. However, the vibration peaks in the Raman spectra are much sharper, suggesting better ordering of $\mathrm{C}_{60}$ polymerization within $\mathrm{C}_{60} \mathrm{~S}_{16}$. It was explained that such ordering is achieved because of the layered structure of the $\mathrm{C}_{60} \mathrm{~S}_{16}$ where the sulfur rings prevent polymerization in the c-axis of monoclinic lattice. The peaks from $S_{8}$ rings disappeared and new peaks were observed at higher pressures. These changes suggested the sulfur rings are broken and covalent C-S bonds may be formed. The Raman spectrum of quenched sample shows some similarities to that of $\mathrm{C}_{60} \mathrm{O}$ suggesting that at least part of the sample consists of $\mathrm{C}_{60} \mathrm{~S}$. [52]

K. P. Meletov and D. V. Konarev recently studied pressure-induced charge transfer transition in the donor-acceptor complexs $\mathrm{C}_{60}\left\{\mathrm{Ni}\left(\mathrm{nPr}_{2} \mathrm{dtc}\right)_{2}\right\}$ and $\mathrm{C}_{60}\left\{\mathrm{Cu}\left(\mathrm{nPr}_{2} \mathrm{dtc}\right)_{2}\right\}$ using Raman spectrograph up to $7 \mathrm{GPa}$ at room temperature. [53] It was found the $\mathrm{Ag}(2)$ mode of $\mathrm{C}_{60}$ split at about $0.7 \mathrm{GPa}$. The peak showed an overall softening by $\sim 6 \mathrm{~cm}^{-1}$ near $2 \mathrm{GPa}$, while the pressure dependence is reversible with some hysteresis. The authors believe that the observed peculiarities are associated with the pressure-induced charge transfer of one electron from the organic donor to the fullerene acceptor. Pressure-induced phase transitions in another molecular donor-acceptor complex $\quad \mathrm{C}_{60}\left\{\mathrm{Pt}(\mathrm{dbdtc})_{2}\right\} \quad\left(\mathrm{C}_{60} \quad\right.$ fullerene with platinum dibenzyldithiocarbamate) were also investigated by the same group up to 8GPa. [54] It was found that the vibration modes related to the $\mathrm{C}_{60}$ split and soften in the low pressure regime $(\mathrm{P}<0.5 \mathrm{GPa})$, indicating the formation of intercage covalent bonds. At the pressure of $\sim 2.5 \mathrm{GPa}$, additional splitting of Raman modes was observed and was attributed to the formation of a polymeric network. The high pressure phase remains stable upon pressure decrease, however the material transforms into a new phase which is different from those of the known polymerized $\mathrm{C}_{60}$ at $0.5 \mathrm{GPa}$. 
The high-pressure study of $m$-xylene solvated $\mathrm{C}_{60}$ up to $60 \mathrm{GPa}$ was studied using a diamond anvil cell by Wang et al. [58] The crystal structure, lattice vibration, and bonding type of the material at high pressures were analyzed experimentally. Surprisingly, there was found to be no drastic changes other than gradual shifts, broadening, and weakening of diffraction peaks. The presence of diffraction peaks at the highest pressures indicates that the long-range periodicity of the molecules remains intact. This is in contrast with pristine pure $\mathrm{C}_{60}$, where the face-centered cubic periodicity of $\mathrm{C}_{60}$ molecular units disappears when it amorphizes above $30 \mathrm{GPa}$. The Raman spectra of the materials recovered from procedures performed at different pressures suggest that $\mathrm{C}_{60}$ cages start to collapse at around $32 \mathrm{GPa}$ and completely transform into amorphous carbon clusters at higher pressures. But, the XRD of the samples recovered from 35 and $42 \mathrm{GPa}$ show clear diffraction peaks of hcp lattice. All these suggest that even $\mathrm{C}_{60}$ cages completely collapse and transform into amorphous clusters at pressures higher than $32 \mathrm{GPa}$. The overall hcp lattice is preserved, forming ordered amorphous carbon clusters (OACC). Figure 10 shows the simulated structures of the materials at different pressures and upon decompression. In-situ high pressure IXS studies suggest the bonding transition of $\mathrm{sp} 2$ to $\mathrm{sp} 3$ during the collapse of $\mathrm{C}_{60}$ at high pressures. To confirm the important role of solvent, a heating treatment was performed for the material recovered from $40 \mathrm{GPa}$ to remove solvent. The treated sample was then studied by XRD. The pattern shows a typical amorphous feature, suggesting that the material loses its long-range periodicity after the solvent is evaporated. This confirms the critical role of the solvent in maintaining long-range periodicity. For practical applications, it is more important that the OACC is quenchable and as incompressible as diamond. Figure 11 shows the optical pictures of the ring cracks in the diamond anvils generated after formation of OACC and then release of the pressure.

Solid-state materials can be categorized by their structures into crystalline (with periodic translation symmetry), amorphous (without periodic or orientational symmetry), and quasi-crystalline (with orientational but not periodic translation symmetry). This study discovered the first crystalline material made with amorphous building blocks. 


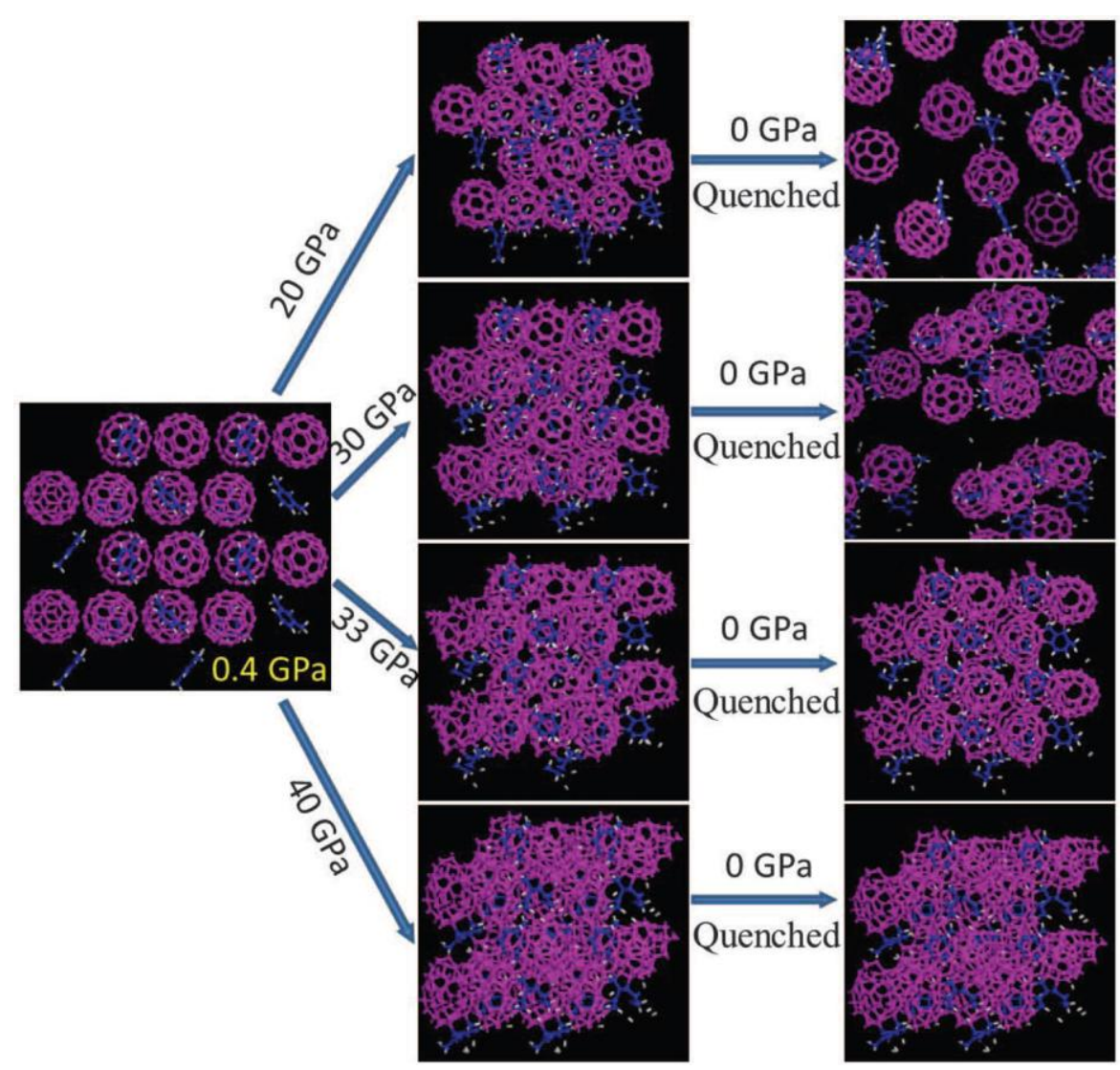

Figure 10. Simulated structures of the material under different compression and decompression conditions. (Reprinted with permission from Wang et al. [58])
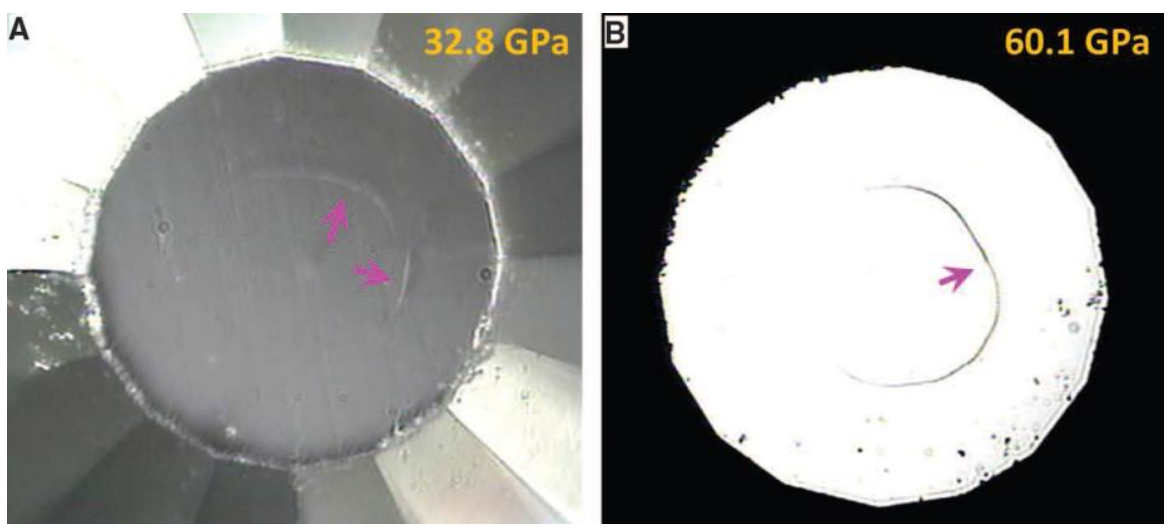

Figure 11. Optical pictures of the ring cracks in the diamond anvils generated after formation of OACC and then release of the pressures from $32.8 \mathrm{GPa}(\mathrm{A})$, and 60.1 $\mathrm{GPa}$ (B). (Reprinted with permission from Wang et al. [58])

After this discovery, Yao et al. studied the behavior of $\mathrm{C}_{60} * m$-xylene solvate and the desolvated $\mathrm{C}_{60}$ using in-situ Raman spectroscopy. [107] The formation of the OACC at high pressure was further confirmed. In the experiments, the structural transformation of solvated and desolvated $\mathrm{C}_{60}$ molecules was found to be similar, both undergoing deformation and amorphization at high pressures. However the mechanical properties of the high-pressure phases are significantly different. The 
high-pressure phase of the solvated sample created clear ring cracks on the diamond anvils, as shown in these experiments at different pressures, confirming previous results. In contrast the desolvated sample created only a very small crack in one experiment, and it is noted that no cracks were produced in another experiment. These suggest that the transformations of the two materials are different due to the presence of solvent. The creation of OACC at high pressures was confirmed directly by HRTEM measurements on decompressed sample. The selected area electron diffraction of OACC can be indexed in a hexagonal structure, which is in constant with our previous XRD result. HRTEM showed the desolvated sample from $44.5 \mathrm{GPa}$ to contain amorphous phase and a small amount of ordered phase. The results indicate that the solvent plays a crucial role in keeping long-range periodicity in the released solvated materials, as concluded in a previous report.

Using Raman spectroscopy, Cui et al. studied high-pressure polymerization of $\mathrm{C}_{60}\left(\mathrm{Fe}\left(\mathrm{C}_{5} \mathrm{H}_{5}\right)_{2}\right)_{2} \quad\left(\mathrm{C}_{60}(\mathrm{Fc})_{2}\right)$ and found a reversible polymerization. In-situ high-pressure Raman studies were carried out on single crystalline $\mathrm{C}_{60}(\mathrm{Fc})_{2}$ molecules at pressures of up to $25.4 \mathrm{GPa}$. [108] The Raman results show that the charge transfer between $\mathrm{Fc}$ (ferrocene) and $\mathrm{C}_{60}$ increases in the low-pressure range. At pressures above $5 \mathrm{GPa}, \mathrm{C}_{60}$ molecules start to form a chainlike polymer structure. However, this polymerization is reversible upon decompression, unlike that of pristine $\mathrm{C}_{60}$. From a structural perspective, the layered structure of $\mathrm{C}_{60}(\mathrm{Fc})_{2}$ restricts the polymerization of $\mathrm{C}_{60}$ molecules in some directions. This explains why only linear chainlike polymeric structures of the $\mathrm{C}_{60}$ lattice form under pressure. It has also been suggested that the reversible polymerization is related to the increased charge transfer and the overridden steric repulsion of counterions.

Similarly, Cui et al. found a reversible pressure-induced polymerization of Fc solvated $\mathrm{C}_{70}$. [109] High-pressure Raman spectroscopy, IR, and XRD were carried out on this solvated fullerene. Theoretical calculations were used to analyze the electron localization function and charge transfer in the crystal to facilitate understanding of the transformation under high-pressure conditions. The results showed that even dimeric and one-dimensional polymeric phases can be formed at about 3 and $8 \mathrm{GPa}$ at room temperature. The polymerization was found to be reversible upon decompression. The reversibility of the polymerization may be related to pressure-tuned transfers of charge and the overridden steric repulsion of counterions, similar to that reported for $\mathrm{C}_{60}(\mathrm{Fc})_{2}$. Fc solvated $\mathrm{C}_{70}$ was also found to have a layered structure of the intercalated ferrocene molecules formed in the crystal. This suggests that ferrocene acts not only as a spacer to restrict the polymerization of $\mathrm{C}_{70}$ molecules within a layer but also as a charge reservoir to tune the polymerization process.

Very recently, the high-pressure behavior of fullerene solvates that form orthorhombic and cubic structures was studied by us. High-pressure behaviors, including phase transformation and polymerization, were not only solvent-dependent but also symmetry-dependent. 
As discussed above, the structure of solvated fullerenes is solvent-dependent and an extensive class of crystalline-solvated fullerenes can be obtained by changing the solvent species and the ratio of fullerenes to solvent. This suggests that the study of solvated fullerenes under high-pressure conditions is only beginning. More investigations are needed, and more phenomena and new discoveries can be expected.

\section{Summary and future prospects}

Studies of solvated fullerenes at high pressure have made a lot of progresses. Because this area of research is just at its beginning, there is a lot of potential yet to be exploited. In particular, phase transition, equation of state, and stability of materials are fundamental questions in physics and material science. The studies shown here indicate that solvents have big impact on the properties of these solvates. However, most of the solvates have not yet been studied and not all of the properties of the solvated materials are known yet. In this way, systematic, high-pressure studies of the solvates are expected. Pristine $\mathrm{C}_{60}$ is a semiconductor. However, the electronic properties of solvated fullerenes and their high pressure phases are still unknown. More experimental and theoretical investigations are expected in near future.

Polymerization of pristine fullerenes under high pressure conditions has become an important topic and many discoveries have been made during the past 20 years. The pressure-induced polymerization of solvated fullerenes is very different from that of pure fullerenes because of the presence of solvent. More systematic studies are also expected in this direction. All these may deepen our understanding of fullerenes and condensed matter.

\section{Acknowledgements}

Acknowledgments: This work was supported as part of EFree, an Energy Frontier Research Center funded by the U.S. Department of Energy (DOE), Office of Science under DE-SC0001057. The work was also supported by the National Natural Science Foundation of China (NSFC, 11004072) and Program for New Century Excellent Talents in University (NCET-10-0444).

\section{References}

1. H. W. Kroto, J. R. Heath, S. C. O'Brien, R. F. Curland, R. E. Smalley, C-60 -Buckminsterfullerene, Nature 318 (1985) 162-163

2. W. Krätschmer, L. D. Lamb, K. Fostiropoulos, D. R. Huffman, Solid C-60 - A new form of carbon, Nature 347 (1990) 354-358.

3. S. Iijima, Helical microtubules of graphitic carbon, Nature 354 (1991) 56-58.

4. K. S. Novoselov, A. K. Geim, S. V. Morozov, D. Jiang, Y Zhang, S. V. Dubonos, I. V. Grigorieva, A. A. Firsov, Electric field effect in atomically thin carbon films, Science 
306 (2004) 666-669.

5. C. N. R. Rao, Ram Seshadri, A. Govindaraj, Rahul Sen, Fullerenes, nanotubes, onions and related carbon structures, Materials Science and Engineering R15 (1995) 209-262.

6. R. E. Smalley, Self-assembly of the fullerenes, Acc. Chem. Res. 25 (1992) 98-105.

7. X. Lu, Z. F. Chen, Curved Pi-conjugation, aromaticity, and the related chemistry of small fullerenes $\left(<\mathrm{C}_{60}\right)$ and single-walled carbon nanotubes, Chem. Review 105 (2005) 3643-3696.

8. F. Diederich, R. L. Whetten, Beyond $\mathrm{C}_{60}$ : the higher fullerenes, Acc. Chem. Res. 25 (1992) 119-126.

9. R. C. Haddon, Electronic structure, conductivity, and superconductivity of alkali metal doped $\mathrm{C}_{60}$, Acc. Chem. Res. 25 (1992) 127-133.

10. Y. F. Zhao, Y. H. Kim, A. C. Dillon, M. J. Heben, S. B. Zhang, Hydrogen storage in novel organometallic buckyballs, Physical Review Letters, 94 (2005) 155504

11. J. L. Segura, N. Martin, D. M. Guldi, Materials for organic solar cells: the $\mathrm{C}_{60} /$ pi-conjugated oligomer approach, Chemical Society Reviews 34 (2005) 31-47.

12. B. C. Thompson, J. M. J. Frechet, Polymer-fullerene composite solar cells, Angew. Chem. Int. Ed. 47 (2008) 58-77.

13. G. J. Zhang, Y. J. He, Y. F. Li, 6.5\% efficiency of polymer solar cells based on poly(3-hexylthiophene) and indene-C-60 bisadduct by device optimization, Advanced Materials, 22 (2010) 4355-4358.

14. H. K. Mao, R. J. Hemley, Ultrahigh-pressure transitions in solid hydrogen, Reviews of Modern Physics 66 (1994) 671-692.

15. R. J. Hemley, A. P. Jephcoat, H. K. Mao, L. C. Ming, M. H. Manghnani, Pressure-induced amorphization of crystalline silica, Nature 334 (1988) 52-54.

16. L. Wang, W. Yang, Y. Ding, Y, Ren, S. Xiao, B. Liu, S. Sinogeikin, Y. Meng, D. J. Gosztola, G. Shen, R.Hemley, W. Mao and H.-k. Mao. Size-dependent amorphization of nanoscale Y2O3 at high pressure. Physics Review Letters 105 (2010) 095701.

17. L. Wang, Y. Ding, W. Yang, W. Liu, Z. Cai, J. Kung, J. Shu, R.J. Hemley, W.Mao, and H.-k. Mao. Nanoprobe measurements of materials at megabar pressures. Proc. Nat. Aca. Sc., 107 (2010) 6140-6145.

18. B. Sundqvist, Fullerenes under high pressure, Advances in Physcis 48 (1999) 1-134.

19. V. D. Blank, S. G. Buga, G. A. Dubitsky, N. R. Serebryanaya, M. Yu. Popov, B. Sundqvist, High-pressure polymerized phases of $\mathrm{C}_{60}$, Carbon 36 (1998) 319-343.

20. B. Sundqvist, Polymeric fullerene phases formed under pressure, Structure and Bonding, 109 (2004) 85-126.

21. F. Giacalone, N. Martin, Fullerene Polymers: Synthesis and properties, Chem. Rev. 106 (2006) 5136-5190.

22. E. Burgos, E. Halac, R. Weht, H. Bonadeo, E. Artacho, P. Ordejon, New superhard phases for three-dimensional $\mathrm{C}_{60}$ based fullerites, Physical Review Letters 85 (2000) 2328-2331.

23. A. F. Hebard, M. J. Rosseinsky, R. C. Haddon, D. W. Murphy, S. H. Glarum, T. T. M. Palstra, A. P. Ramirez, A. R. Kortan, Superconductivity at $18 \mathrm{~K}$ in potassium-doped $\mathrm{C}_{60}$, Nature 350 (1991) 600-601.

24. P. W. Stephens, L. Mihaly, P. L. Lee, R. L. Whetten, S. M. Huang, R. Kaner, F. Deiderich, K. Holczer, Structure of single-phase superconducting $\mathrm{K}_{3} \mathrm{C}_{60}$, Nature 351 (1991) 632-634. 
25. R. M. Fleming, A. P. Ramirez, M. J. Rosseinsky, D. W. Murphy, R. C. Haddon, S. M. Zahurak, A. V. Makhija, Relation of structure and superconducting transitiontemperatures in $\mathrm{A}_{3} \mathrm{C}_{60}$, Nature 352 (1991) 787-788.

26. R. M. Fleming, A. R. Kortan, B. Hessen, T. Siegrist, F. A. Thiel, P. Marsh, R. C. Haddon, R. Tycko, G. Dabbagh, M. L. Kaplan, A. M. Mujsce, Pseudotenfold symmetry in pentane-solvated $\mathrm{C}_{60}$ and $\mathrm{C}_{70}$, Physical Review B 44 (1991) 888-891.

27. F. Michaud, M. Barrio, D. O. Lo'pez, J. Ll. Tamarit, V. Agafonov, S. Toscani, H. Szwarc, R. Ce'olin, Solid-state studies on a $\mathrm{C}_{60}$ solvate grown from 1,1,2-Trichloroethane, Chemistry of Materials 12 (2000) 3595-3602.

28. L. Wang, B. B. Liu, S. D. Yu, M. G. Yao, D. D. Liu, Y. Y. Hou, T. Cui, G. T. Zou, B. Sundqvist, Highly Enhanced Luminescence from Single-Crystalline $\mathrm{C}_{60} * 1 \mathrm{~m}$-xylene Nanorods. Chemistry of Materials18 (2006) 4190.

29. L. Wang, B. B. Liu, D. D. Liu, M. G. Yao, Y. Y. Hou, S. D. Yu, T. Cui, D. M. Li, G. T. Zou, A. Iwasiewicz, B. Sundqvist, Synthesis of Thin, Rectangular $\mathrm{C}_{60}$ Nanorods Using m-Xylene as a Shape Controller. Advanced Materials 18 (2006) 1883.

30. I. E. Grey, M. J. Hardie, T. J. Ness, and C. L. Raston, Octaphenylcyclotetrasiloxane confinement of $\mathrm{C}_{60}$ into double columnar arrays, Chem. Commun., (1999) 1139 - 1140.

31. A. Talyzin, U. Jansson, $\mathrm{C}_{60}$ and $\mathrm{C}_{70}$ solvates studied by Raman spectroscopy, J. Phys. Chem. B 104 (2000) 5064-5071.

32. M. Barrio, D. O. Lo’́pez, J. Ll. Tamarit, P. Espeau, R. Ce'olin, H. Allouchi, Solid-State Studies of $\mathrm{C}_{60}$ Solvates Formed in the $\mathrm{C}_{60}-\mathrm{BrCCl}_{3}$ System, Chem. Mater. 15 (2003) 288-291.

33. R. Ce'olin, J. L. Tamarit, M. Barrio, D. O. Lo'pez, P. Espeau, H. Allouchi, R. J. Papoular, Solid state studies of the $\mathrm{C}_{60} .2\left(\mathrm{CH}_{3}\right) \mathrm{CCl}_{3}$ solvate, Carbon 43 (2005) 417-424.

34. H. B. Bürgi, R. Restori, D. Schwarzenbach, A. L. Balch, J. W. Lee, B. C. Noll, M. M. Olmstead, Nanocrystalline domains of a monoclinic modification of benzene stabilized in a crystalline matrix of $\mathrm{C}_{60}$, Chem. Mater. 6 (1994) 1325-1329.

35. H. He, J. Barras, J. Foulkes, J. Klinowski, Solid-state NMR studies of fullerene $\mathrm{C}_{60}$ /benzene solvates, J. Phys. Chem. B 101 (1997) 117-122.

36. M. F. Meidine, P. B. Hitchcock, H. W. Kroto, R. Taylor, D. R. M. Walton, Single crystal X-ray structure of benzene-solvated $\mathrm{C}_{60}$, J. Chem. Soc., Chem. Commun. (1992) 1534-1537.

37. S. Pekker, G. Faigel, K. Fodor-Csorba, L. Gránásy, E. Jakab, M. Tegze, Structure and stability of crystalline $C_{60} * n$-pentane clathrate, Solid State Commun 83 (1992) 423-426.

38. S. Toscani, H. Allouchi, J. L. Tamarit, D. O. López, M. Barrio, V. Agafonov, V. Agafonov, A. Rassat, H. Szwarc, R. Ce'olin, Decagonal $\mathrm{C}_{60}$ crystals grown from n-hexane solutions: solid-state and aging studies, Chem Phys. Lett. 330 (2000) 491-496.

39. R. Ceolin, V. Agrafonov, B. Bachet, A. Gonthiervassal, H. Szwarc, S. Toscani, G. Keller, C. Fabre, A. Rassat, Solid-state studies on $\mathrm{C}_{60}$ solvates grown from n-heptane, Chem. Phys. Lett. 244 (1995) 100-104.

40. X. D. Shi, A. R. Kortan, J. M. Williams, A. M. Kini, B. M. Savall, and P. M. Chaikin, Sound velocity and attenuation in single-crystal $\mathrm{C}_{60}$, Phys. Rev. Lett. 68 (1992) 827-830. 
41. K. Kikuchi, S. Suzuki, K. Saito, H. Shiromaru, A. A. Zakhidov, A. Ugawa, K. Imaeda, H. Inokuchi, K. Yakushi, Structure and superconductivity of single crystalline $\mathrm{C}_{60}$, Physica $\mathrm{C}$ 185 (1991) 415-416.

42. S. M. Gorun, K. M. Creegan, R. D. Sherwood, D. M. Cox, V. W. Day, C. S. Day, R. M. Upton and C. E. Briant, Solvated $\mathrm{C}_{60}$ and $\mathrm{C}_{60} / \mathrm{C}_{70}$ and the low-resolution single crystal X-ray structure of $\mathrm{C}_{60}$, J. Chem. Soc., Chem. Commun., (1991) 1556-1558.

43. A. L. Balch, J. W. Lee, B. C. Noll, M. M. Olmstead, Disorder in a crystalline form of buckminsterfullerene: $\mathrm{C}_{60} * 4 \mathrm{C}_{6} \mathrm{H}_{6}$, J. Chem. Soc., Chem. Commun. (1993) 56-58.

44. A. Graja, R. Swietlik, Temperature study of IR-spectra of some $\mathrm{C}_{60}$ compounds, Synth. Met. 70 (1995) 1417-1418.

45. R. Swietlik, P. Byszewski, E. Kowalska, Interactions of $\mathrm{C}_{60}$ with organic molecules in solvate crystals studied by infrared spectroscopy, Chem. Phys. Lett. 254 (1996) 73-78.

46. Iwasiewicz-Wabnig, B. Sundqvist, É. Kováts, I. Jalsovszky, S. Pekker, Polymerization of the rotor-stator compound $\mathrm{C}_{60}$-cubane under high pressure. Phys. Rev. B 75 (2007), 024114

47. Iwasiewicz-Wabnig, R. Röding, B. Sundqvist, É. Kováts, I. Jalsovszky, S. Pekker, Pressure-temperature phase diagram of the rotor-stator compound $\mathrm{C}_{60}$-cube. Solid State Communications 143 (2007) 208-212.

48. K. Thirunavukkuarasu, C. A. Kuntscher, B. J. Nagy, I. Jalsovszky, G. Klupp, K. Kamarás, É. Kováts, S. Pekker, Orientational ordering and intermolecular interactions in the rotor-stator compounds $\mathrm{C}_{60}-\mathrm{C}_{8} \mathrm{H}_{8}$ and $\mathrm{C}_{70}-\mathrm{C}_{8} \mathrm{H}_{8}$ studied under high pressure. J. Phys. Chem. C 112 (2008) 17525-17532.

49. C. A. Kuntscher, S. Frank, K. Kamarás, G. Klupp, É. Kováts, S. Pekker, Gy. Bényei, I. Jalsovszky, Pressure-dependent infrared spectroscopy on the fullerene rotor-stator compound $\mathrm{C}_{60}-\mathrm{C}_{8} \mathrm{H}_{8}$. Phys. Status Solidi B 243 (2006) 2981-2984.

50. E. A. Francis, G. Durkó, I. Jalsovszky, G. Klupp, K. Kamarás, É. Kováts, S. Pekker, C. A. Kuntscher, Phase transitions in $\mathrm{C}_{60}-\mathrm{C}_{8} \mathrm{H}_{8}$ under hydrostatic pressure. Phys. Status Solidi B 249 (2012) 2596-2599.

51. Iwasiewicz-Wabnig, É. Kováts, S. Pekker, B. Sundqvist, Low-temperature optical studies of $\mathrm{C}_{60}$-cubane rotor-stator compound. Journal of Physics: Conference Series 100 (2008) 052091.

52. A. V. Talyzin, L. S. Dubrovinsky, U. Jansson, High pressure Raman study of $\mathrm{C}_{60} \mathrm{~S}_{16}$. Solid State Communications 123 (2002) 93-96.

53. K. P. Meletov, D. V. Konarev, Raman study of the pressure-induced charge transfer transition in the neutral donor-acceptor complexes $\left\{\mathrm{Ni}\left(\mathrm{nPr}_{2} \mathrm{dtc}\right)_{2}\right\}\left(\mathrm{C}_{60}\right)_{2}$ and $\left\{\mathrm{Cu}\left(\mathrm{nPr} \mathrm{Pr}_{2} \mathrm{dtc}\right)\right.$ $\left.{ }_{2}\right\}\left(\mathrm{C}_{60}\right)_{2}$. Fullerenes, Nanotubes and Carbon Nanostructures, 20:4-7, 336-340.

54. K. P. Meletov, D. V. Konarev, Raman study of the pressure-induced phase transitions in the molecular donor-acceptor complex $\left\{\mathrm{Pt}(\mathrm{dbdtc})_{2}\right\} \mathrm{C}_{60}$. Chemical Physics Letters 553 (2012) 21-25.

55. G. Sparn, J. D. Thompson, P. -M. Allemand, Q. Li, F. Wudl, K. Holczer, P. W. Stephens, Pressure dependence of magenetism in $\mathrm{C}_{60}$ TDAE. Solid State Communications 82 (1992) 779-782. 
56. K. Mizoguchi, M. Machino, H. Sakamoto, T. Kawamotor, M. Tokumoto, A. Omerzu, D. Mihailovic, Pressure effect in TDAE- $\mathrm{C}_{60}$ ferromagnet: Mechanism and polymerization. Physical Review B 63 (2001) 140417.

57. K. Mizoguchi, M. Takei, H. Sakamoto, T. Kawamotor, M. Tokumoto, A. Omerzu, D. Mihailovic, Uniaxial strain study in purely organic ferromagnet $\alpha$-TDAE-C ${ }_{60}---$ mechanism and structure. Polyhedron 24 (2005) 2173-2175.

58. L. Wang, B. Liu, H. Li, W. Yang, Y. Ding, S. Sinogeikin, Y. Meng, Z. Liu, X. Zeng. Ultra-incompressible Three Dimensional Long-range Ordered Amorphous Carbon Clusters. Science, 337 (2012) 825-825.

59. D. E. H. Jones, New Scientist, 35 (1966) 245.

60. D. E. H. Jones, The inventions of Daedalus, W. H. Freeman, Oxford, 1982, p.118.

61. R. S. Ruoff, A. L. Ruoff, Is $\mathrm{C}_{60}$ stiffer than diamond, Nature, 350 (1991) 663-664.

62. R. S. Ruoff, A. L. Ruoff, The bulk modulus of $\mathrm{C}_{60}$ molecules and crystals - a molecular mechanics approach, Applied Physics Letters, 59 (1991) 1553-1555.

63. H. J. Mcskimin, W. L. Bond, Elastic moduli of diamond, Physical Review, 105 (1957) 116-121.

64. J. E. Fischer, P. A. Heiney, A. R. McGhie, W. J. Romanow, A. M. Denenstein, J. P. McCauley, Jr., and A. B. Smith, Compressibility of solid C60, Science 252 (1991) 1288-1290.

65. L. Wang, B. B. Liu, D. D. Liu, M. G. Yao, S. D. Yu, Y. Y. Hou, T. Cui, G. T. Zou, B. Sundqvist, Z. J. Luo, H. Li, Y. C. Li, J. Liu, S. J. Chen, G. R. Wang, Y. C. Liu, Synthesis and High Pressure Induced Amorphization of $\mathrm{C}_{60}$ Nanosheets. Applied Physics Letters 91, (2007) 103112.

66. L. Wang, B. B. Liu, D. D. Liu, Y. Y. Hou, M. G. Yao, G. T. Zou, H. Li, Z. J. Luo, Y. C. Li, J. Liu, B. Sundqvist, High pressure studies of nano/sub-micrometer C-70 rods, High Energy Physics and Nuclear Physics-Chinese Edition, 29 (2005) 112-115.

67. J. Y. Hu, N. N. Niu, G. Z. Piao, Y. Yang, Q. Zhao, Y. Yao, C. Z. Gu, C. Q. Jin, R. C. Yu, Phase transitions in single crystal tubes formed from $\mathrm{C}_{60}$ molecules under high pressure, Carbon, 50 (2012) 5458-5462.

68. J. Yang, C. L. Liu, C. X. Gao, In-situ electrical resistance and activation energy of solid $\mathrm{C}_{60}$ under high pressure, Chinese Physics B, 22 (2013) 096202.

69. D. D. Liu, M. G. Yao, Q. J. Li, W. Cui, L. Wang, Z. P. Li, B. Liu, H. Lv, B. Zou, T. Cui, B. B. Liu, B. Sundqvist, In-situ Raman and photominescence study on pressure-induced phase transition in $\mathrm{C}_{60}$ nanotubes, Journal of Raman Spectroscopy, 43 (2012) 737-740.

70. D. D. Liu, M. G. Yao, L. Wang, Q. J. Li, W. Cui, B. Liu, R. Liu, B. Zou, T. Cui, B. B. Liu, J. Liu, B. Sundqvist, T. Wagberg, Pressure-induced phase transitions of $\mathrm{C}_{70}$ nanotubes, Journal of Physical Chemistry C, 115 (2011) 8918-8922.

71. L. Pintschovius, O. Blaschko, G. Krexner, N. Pyka, Bulk modulus of $\mathrm{C}_{60}$ studied by single-crystal neutron diffraction, Physical Review B, 59 (1999) 11020-11026.

72. F. Moshary, N. H. Chen, I. F. Silvera, C. A. Brown, H. C. Dorn, M. S. de Vries, and D. S. Bethune, Gap reduction and the collapse of solid $\mathrm{C}_{60}$ to a new phase of carbon under high pressure, Phys. Rev. Lett. 69 (1992) 466-469. 
73. H. Yanawaki, M. Yoshida, Y. Kakudate, S. Usuba, H. Yokoi, S. Fujiwara, K. Aoki, R. Ruoff, R. Malhotra, D. Lorents, Infrared study of vibrational property and polymerization of $C_{60}$ and $C_{70}$ under pressure, Journal of Physical Chemistry, 97 (1993) 11161-11163.

74. S. J. Duclos, K. Brister, R. C. Haddon, A. R. Kortan, F. A. Thiel, Effects of pressure and stress on $\mathrm{C}_{60}$ fullerite to $20 \mathrm{GPa}$, Nature, 351 (1991) 380-382.

75. V. A. Davydov, L. S. Kashevarova, A. V. Rakhmanina, V. Agafonov, H. Allouchi, R. Ce'olin, A. V. Dzyabchenko, V. M. Senyavin, H. Szwarc, T. Tanaka, and K. Komatsu, Particularities of $\mathrm{C}_{60}$ Transformations at $1.5 \mathrm{GPa}$, J. Phys. Chem. B 103 (1999) 1800-1804.

76. Y. Iwasa, T. Arima, R. M. Fleming, T. Siegrist, O. Zhou, R. C. Haddon, L. J. Rothberg, K. B. Lyons, H. L. Carter, A. F. Hebard, R. Tycko, G. Dabagh, J. J. Krajewski, G. A. Thomas, T. Yagi, New phases of $C_{60}$ synthesized at high pressure, Science, 264 (1994) 1570-1572.

77. I. O. Bashkin, V. I. Rashchupkin, A. F. Gurov, A. P. Moravsky, O. G. Rybchenko, N. P. Kobelev, Y. M. Soifer, E. G. Ponyatovskii, A new phase transition in the T-P diagram of C $_{60}$ fullerite, J. Phys: Condens. Matter. 36 (1994) 7491.

78. P. A. Persson, U. Edlund, P. Jacobsson, D. Johnels, A. Soldatov, B. Sundqvist, NMR and Raman characterization of pressure polymerized $C_{60}$, Chemical Physics Letters 258 (1996) 540-546.

79. M. Nunez-Regueiro, L. Marques, J. L. Hodeau, O. Bethoux, M. Perroux, Polymerized fullerite structures, Physical Review Letters, 74 (1995) 278-281.

80. L. A. Chernozatonskii, N. R. Serebryanaya, The superhard crystalline three-dimensional polymerized $\mathrm{C}_{60}$ phase. Chemical Physics Letters 316 (2000) 199-204.

81. N. R. Serebryanaya, L. A. Chernozatonskii, Modelling and interpretation of the experimental data on the $3 \mathrm{D}$ polymerized $\mathrm{C}_{60}$ fullerites. Solid State Communications 114 (2000) 537-541.

82. L. Marques, M. Mezouar, J.-L. Hodeau, M. Núñez-Regueiro, N. R. Serebryanaya, V. A. Ivdenko, V. D. Blank, G. A. Dubitsky, "Debye-Scherrer Ellipses" from 3D fullerene polymers: an anisotropic pressure memory signature. Science 283 (1999) 1720-1723.

83. M. Mezouar, L. Marques, J.-L. Hodeau, V. Pischedda, M. Núñez-Regueiro, Equation of state of an anisotropic three-dimensional $\mathrm{C}_{60}$ polymer: the most stable form of fullerene. Physical Review B 68 (2003) 193414.

84. V. D. Blank, S. G. Buga, G. A. Dubitsky, N. R. Serebryanaya, S. N. Sulyanov, M. Yu. Popov, in Molecular Nanostructures, ed. H. Kuzmany, J. Fink, M. Mehring and S. Roth. World Scientific, Singapore, 1998 pp.506-510.

85. V. D. Blank, S. G. Buga, N. R. Serebryanaya, V. N. Denisov, G. A. Dubitsky, A. N. Ivlev, B. N. Mavrin, M. Yu. Popov, Ultrahard and superhard carbon phases produced from $\mathrm{C}_{60}$ by heating at high pressure : structural and Raman studies, Physics Letters A 205 (1995) 208-216.

86. V. D. Blank, S. G. Buga, G. A. Dubitsky, N. R. Serebryanaya, V. N. Denisov, A. N. Ivlev, B. N. Mavrin, M. Yu. Popov, Synthesis of ultrahard and superhard materials from $\mathrm{C}_{60}$ fullerite, Molecular Crystals and Liquid Crystals Science and Technology Section C - Mol. Mater. 7 (1996) 251-256.

87. S. Wasa, K. Suito, M. Kobayashi, A. Onodera, Pressure-induced irreversible amorphization of $\mathrm{C}_{70}$ fullerene, Solid State Communications, 114 (2000) 209-213. 
88. S. Lebedkin, W. E. Hull, A. V. Soldatov, B. Renker, M. M. Kappes, Journal of Physical Chemistry B 104 (2000) 4101.

89. A. V. Soldatov, G. Roth, A. Dzyabchenko, D. Johnels, S. Lebedkin, C. Meingast, B. Sundqvist, M. Haluska, H. Kuzmany, Science 293 (2001) 860.

90. V. D. Blank, N.R. Serebryanaya, G. A. Dubitsky, S. G. Buga, V. N. Denisov, B. N. Mavrin, I. N. Ivlev, S. N. Sulyanov, N. A. Lvova, Physics Letters A 248 (1998) 415.

91. R. S. Ruoff, D. S. Tse, R. Malhotra, D. C. Lorents, Solubility of $\mathrm{C}_{60}$ in a variety of solvents, J. Phys. Chem. 97 (1993) 3379-3383.

92. A. Demortier, R. Doome, A. Fonseca, J. B. Nagy, Study of the anomalous solubility behavior of solutions saturated with fullerenes by C13-NMR, Magnetic Resonance in Colloid and Interface Science - NATO Science Series, 76 (2002) 513-518.

93. R. E. Haufler, J. Conceicao, L. P. F. Chibante, Y. Chai, N. E. Byrne, S. Flanagan, M. M. Haley, S. C. Obrien, C. Pan, Z. Xiao, W. E. Billups, M. A. Ciufolini, R. H. Hauge, J. L. Margrave, L. J. Wilson, R. F. Curl, R. E. Smalley, Efficient production of $\mathrm{C}_{60}$ (Buckminsterfullerene), $\mathrm{C}_{60} \mathrm{H}_{36}$, and the solvated buckide ion, Journal of Physical Chemistry 94 (1990) 8634-8636.

94. M. V. Korobov, E. B. Stukalin, A. L. Mirakyan, I. S. Neretin, Y. L. Slovokhotov, A. V. Dzyabchenko, A. I. Ancharov, B. P. Tolochko, New solid solvated of $\mathrm{C}_{60}$ and $\mathrm{C}_{70}$ fullerenes: the relationship between structures and lattice energies, Carbon, 41 (2003) 2743-2755.

95. A. K. Gangopadhyay, J. S. Schilling, M. D. Leo, W. E. Buhro, K. Robinson, T. Kowalewski, Synthesis and characterization of $\mathrm{C}_{60}\left[\mathrm{CCl}_{4}\right]_{10}$, Solid State Communications, 96 (1995) 597-600.

96. C. Collins, J. Foulkes, A. D. Bond, J. Klinowski, Crystalline $\mathrm{C}_{60} * 2 \mathrm{CHBr}_{3}$ : a solid-state study, Phys. Chem. Chem. Phys. 1 (1999) 5323-5326.

97. R. Ceolin, J. L1. Tamarit, M. Barrio, D. O. Lopez, S. Toscani, H. Allouchi, V. Agafonov, $\mathrm{H}$. Szwarc, Solid-state studies on a cubic 1:1 solvate of $\mathrm{C}_{60}$ grown from dichloromethane and leading to another hexagonal $\mathrm{C}_{60}$ polymorph, Chemistry of Materials, 13 (2001) 1349-1355.

98. P. Espeau, M. Barrio, D. O. Lopez, J. L1. Tamarit, R. Ceolin, H. Allouchi, V. Agafonov, F. Masin, H. Szwarc, Phase equilibria in the $\mathrm{C}_{60}+$ Ferrocene system and solid-state studies of the $\mathrm{C}_{60} * 2$ Ferrocene solvate, Chemistry of Materials, 14 (2002) 321-326.

99. M. Barrio, D. O. Lopez, J. L1. Tamarit, P. Espeau, R. Ceolin, H. Allouchi, Solid-state studies of $\mathrm{C}_{60}$ solvates formed in the $\mathrm{C}_{60}-\mathrm{BrCCl}_{3}$ system, Chemistry of Materials, 15 (2003) 288-291.

100. R. Ceolin, D. O. Lopez, M. Barrio, J. L1. Tamarit, P. Espeau, B. Nicolai, H. Allouchi, R.Papoular, Solid state studies on $\mathrm{C}_{60}$ solvates formed with n-alcanes: orthorhombic $\mathrm{C}_{60} * 2 / 3 n$-nonane, Chemical Physics Letters, 399 (2004) 401-405.

101. M. M. Olmstead, L. J. Hao, A. L. Balch, Preparation and crystallographic studies of $\mathrm{C}_{70} \mathrm{Pd}\left(\mathrm{PPh}_{3}\right)_{2} * \mathrm{CH}_{2} \mathrm{Cl}_{2}$ and $\mathrm{C}_{70} * 2\left(\left(\mathrm{C}_{5} \mathrm{H}_{5}\right)_{2} \mathrm{Fe}\right)$, Journal of Organometallic Chemistry, 578 (1999) 85-90.

102. C. Park, E. Yoon, M. Kawano, T. Joo, H. C. Choi, Self-crystallization of $\mathbf{C}_{70}$ cubes and remarkable enhancement of photoluminescence, Angewandte Chemie-International Edition, 49 (2010) 9670-9675. 
103. S. Pekker, É. Kováts, G. Oszlányi, G. Bényei, G. Klupp, G. Bortel, I. Jalsovszky, E. Jakab, F. Borondics, K. Kamarás, M. Bokor, G. Kriza, K. Tompa, G. Faigel, Rotor-stator molecular crystals of fullerenes with cubane, Nature Materials 4 (2005) 764-767.

104. G. Bortel, G. Faigel, É. Kováts, G. Oszlányi and S. Pekker, Structural study of $\mathrm{C}_{60}$ and $\mathrm{C}_{70}$ cubane, Physica Status Solidi (b) 243 (2006) 2999-3003.

105. A. Talyzin, U. Jansson, Preparation and characterization of $\mathrm{C}_{60} \mathrm{~S}_{16}$ and $\mathrm{C}_{70} \mathrm{~S}_{48}$ thin films, Thin Solid Films 350 (1999) 113-118.

106. F. Masin, A. -S. Grell, I. Messari, G. Gusman, Benzene-solvated $\mathrm{C}_{60}$ : $1 \mathrm{H}$ nuclear spin-lattice magnetic relaxation, Solid State Communications, 106 (1998) 59-62.

107. M. G. Yao, W. Cui, J. P. Xiao, S. L. Chen, J. X. Cui, R. Liu, T. Cui, B. Zou, B. B. Liu, B. Sundqvist, Pressure-induced transformation and superhard phase in fullerenes: the effect of solvent intercalation, Applied Physics Letters, 103 (2013) 071913.

108. W. Cui, M. G. Yao, D. D. Liu, Q. J. Li, R. Liu, B. Zou, T. Cui, B. B. Liu, Reversible polymerization in doped fullerides under pressure: the case of $\mathrm{C}_{60}\left(\mathrm{Fe}\left(\mathrm{C}_{5} \mathrm{H}_{5}\right)_{2}\right)_{2}$, Journal of Physical Chemistry B, 116 (2012) 2643-2650.

109. W. Cui, M. G. Yao, Z. Yao, F. X Ma, Q. J. Li, R. Liu, B. Liu, B. Zou, T. Cui, B. B. Liu, B. Sundqvist, Reversible pressure-induced polymerization of $\mathrm{Fe}\left(\mathrm{C}_{5} \mathrm{H}_{5}\right)_{2}$ doped $\mathrm{C}_{70}$, Carbon, 62 (2013) 447-454.

110. K. Mizoguchi, M. Takei, M. Machino, H. Sakamoto, M. Tokumoto, T. Kawamoto, A. Omerzu, and D. Mihailovic, Magnetism of $\alpha$ - and $\beta$-TDAE-C ${ }_{60}$, J. Mag. Mag. Mat. 272 (2004) E215.

111. D. Arčon, R. Blinc, P. Cevc, and A. Omerzu, Evidence for $\mathrm{S}=0$-type spin pairing in the nonferromagnetic modification of TDAE- $\mathrm{C}_{60}$, Physical Review B 59 (1999) 5247. 


\section{Figure captions}

Figure 1. The structures of $\mathrm{C}_{60}$ and $\mathrm{C}_{70}$ molecules.

Figure 2. Phase diagram of $\mathrm{C}_{60}$ showing the structural phases obtained under the pressure-temperature conditions shown. (Reprinted with permission from B. Sundqvist [20])

Figure 3. Basic structures of the three low-dimensional phases of $\mathrm{C}_{60}$. (Reprinted with permission from B. Sundqvist [20])

Figure 4. Pressure-temperature phase diagram of $\mathrm{C}_{70}$. (Reprinted with permission from B. Sundqvist [20])

Figure 5. SEM images of as-grown $\mathrm{C}_{60} * 1 m$-xylene solvate nanorods. $[28,29]$ (Reprinted with permission from Wang et al. [29])

Figure 6. PL spectra of $\mathrm{C}_{60} * m$-xylene solvate and pristine $\mathrm{C}_{60}$ (A), and $\mathrm{C}_{70} * 2$ mesitylene solvate and pristine $\mathrm{C}_{70}$ powder (B). (Adapted from [28] and [102])

Figure 7. Tc versus $\mathrm{P} 50 \mathrm{~K}$ in $\mathrm{C}_{60} * \mathrm{TDAE}$. The solid curve indicates the theoretical predition with the data up to $7.4 \mathrm{kbar}$. (Reprinted with permission from Mizoguchi et al. [56])

Figure 8. Tc variations caused by uniaxial strain along b-axis [110] and c-axis, together with by hydrostatic pressure [111] (Reprinted with permission from Mizoguchi et al. [57])

Figure 9. Pressure-temperature phase diagram of $\mathrm{C}_{60} * \mathrm{C}_{8} \mathrm{H}_{8}$. (Reprinted with permission from Iwasiewicz-Wabnig et al. [47])

Figure 10. Simulated structures of the material under different compression and decompression conditions. (Reprinted with permission from Wang et al. [58])

Figure 11. Optical pictures of the ring cracks in the diamond anvils generated after formation of OACC and then release of the pressures from $32.8 \mathrm{GPa}$ (A), and 60.1 GPa (B). (Reprinted with permission from Wang et al. [58]) 

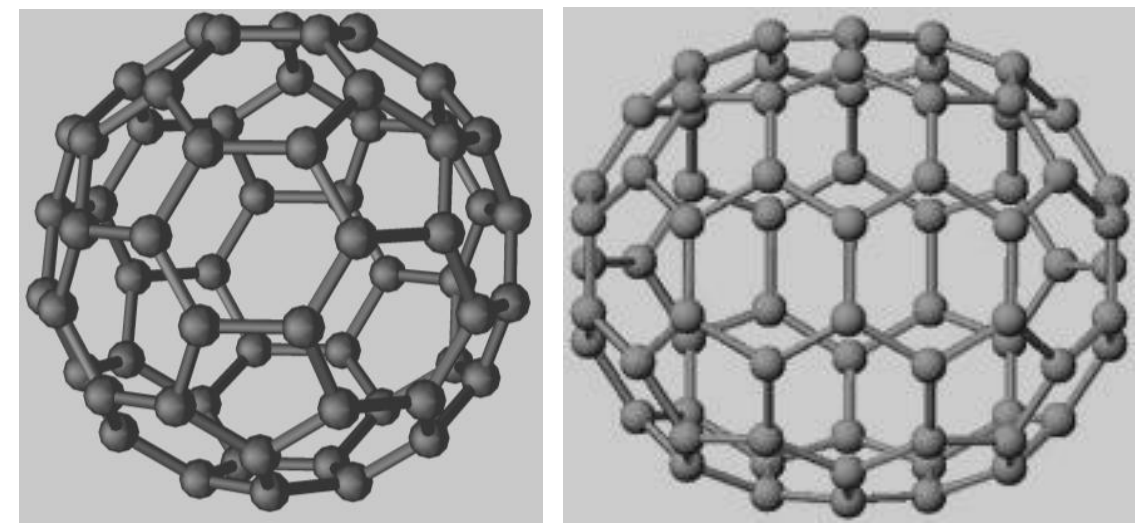

Figure 1.

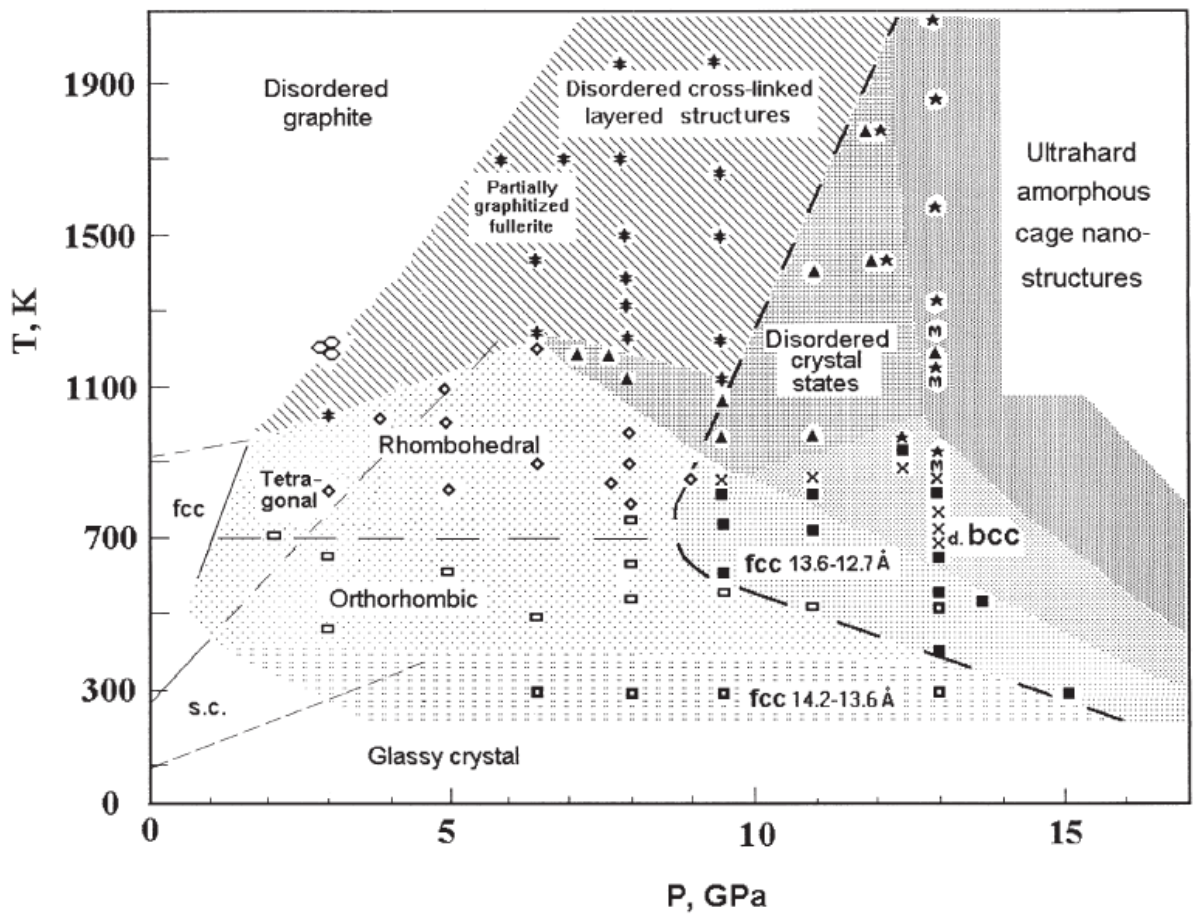

Figure 2. 


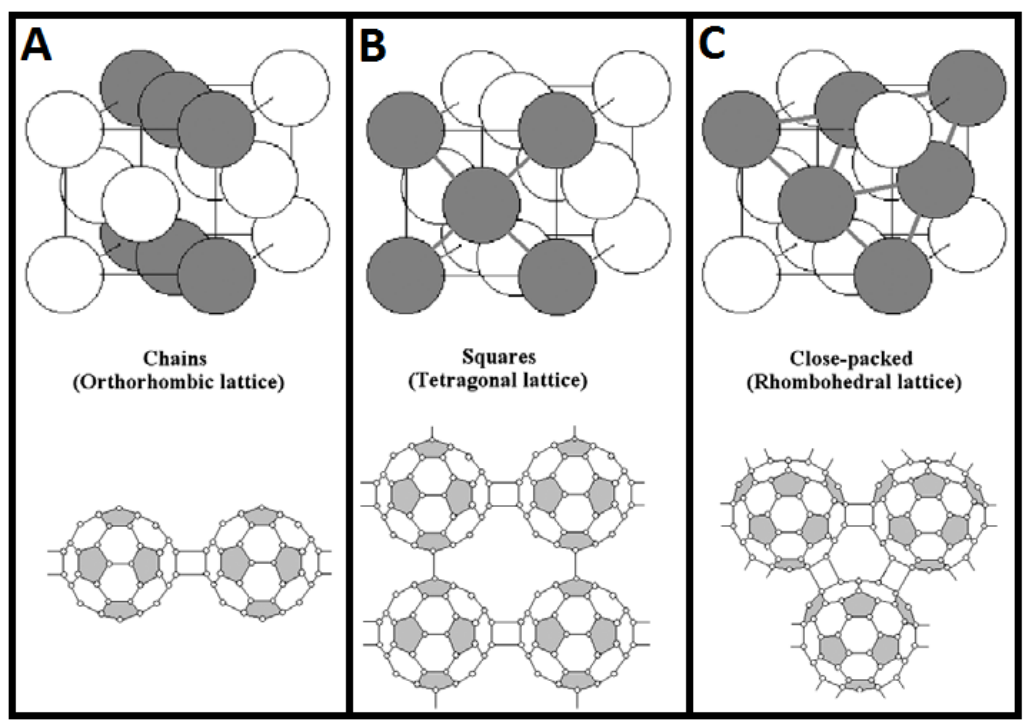

Figure 3.

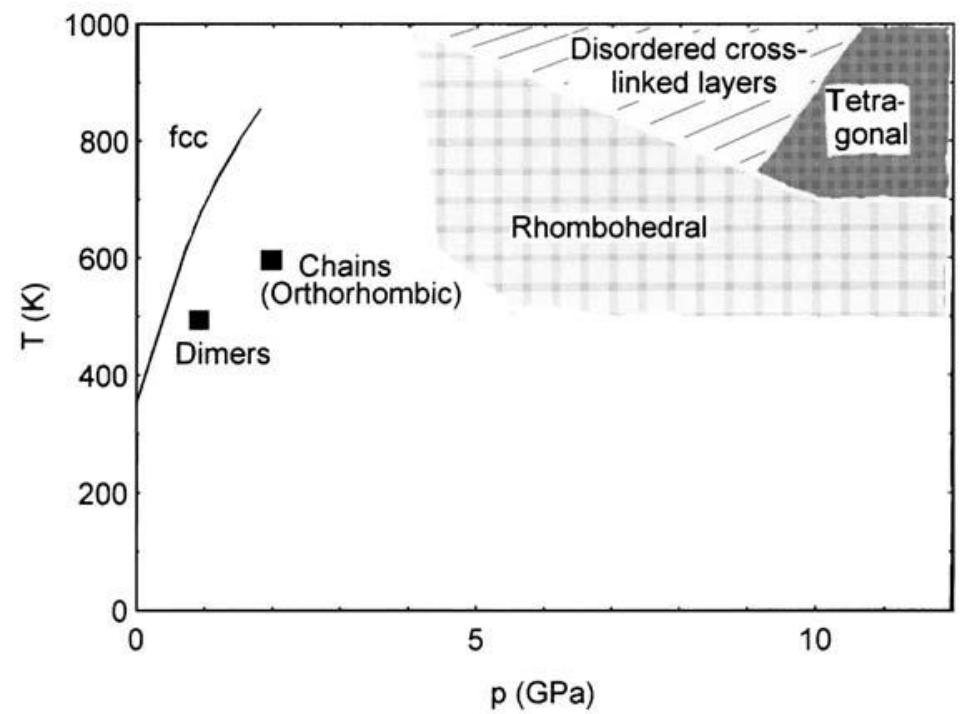

Figure 4. 


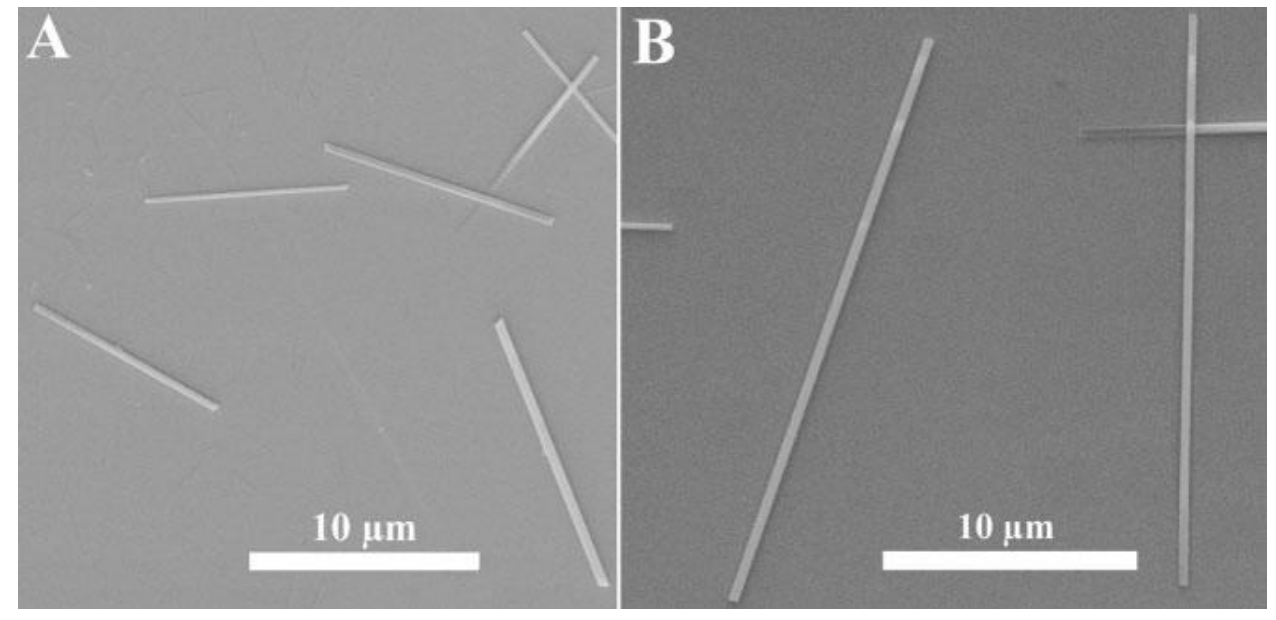

Figure 5.
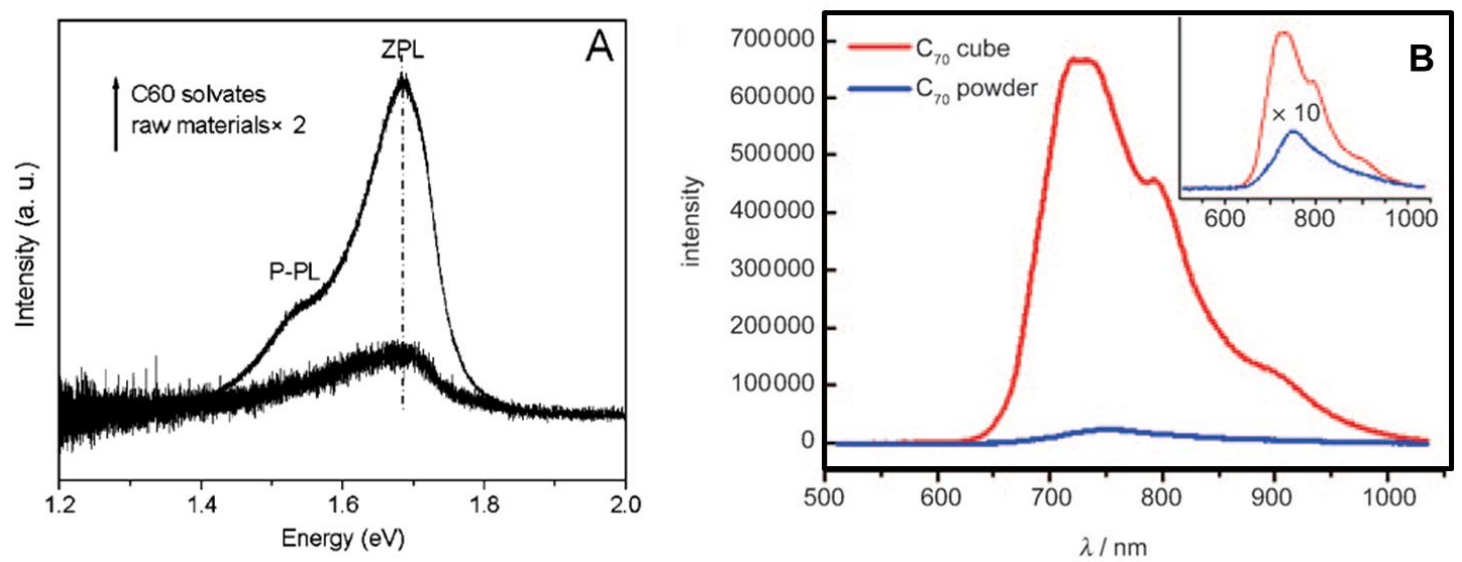

Figure 6.

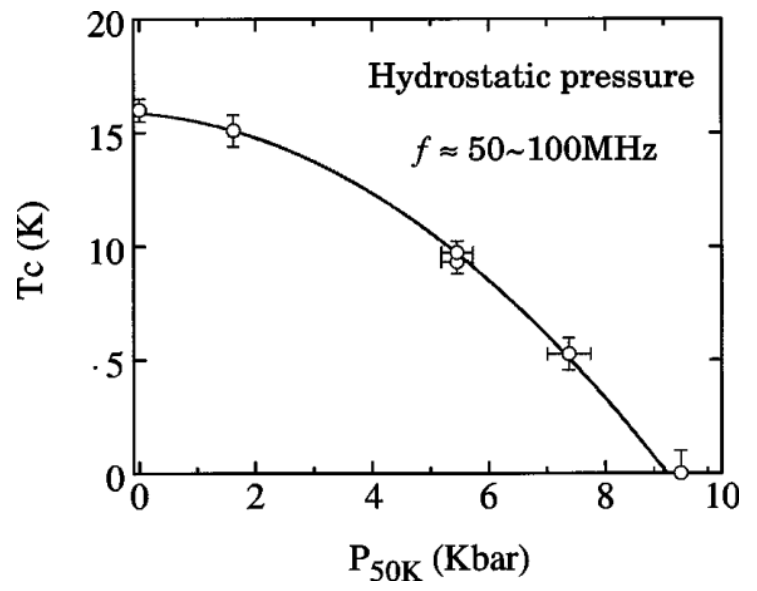

Figure 7. 


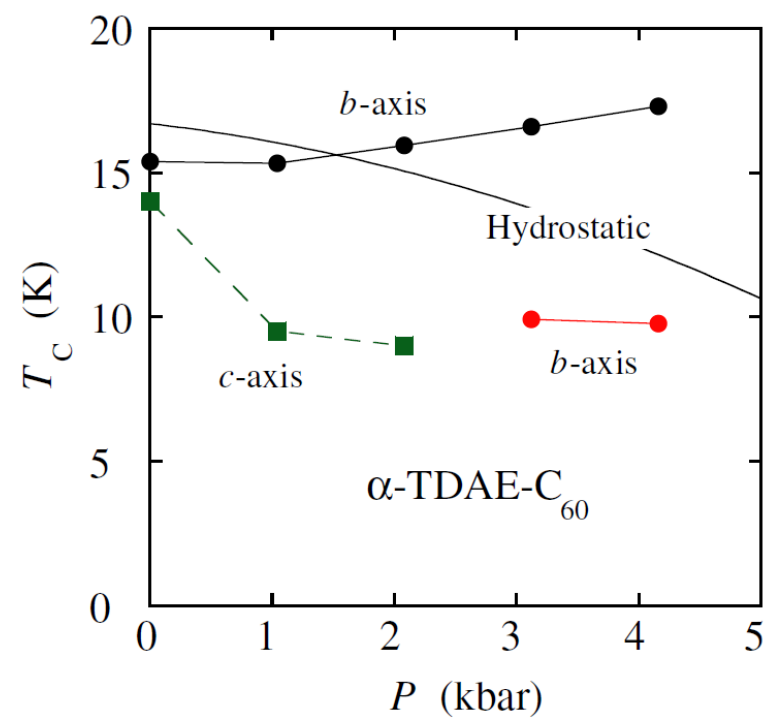

Figure 8.

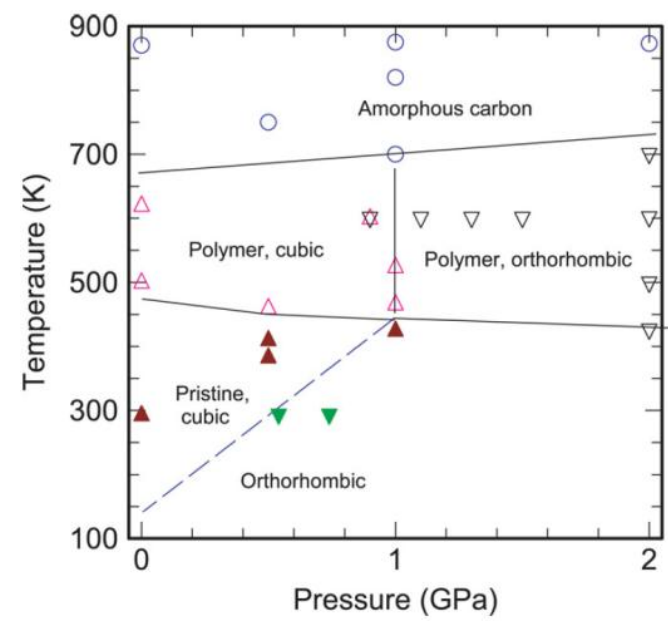

Figure 9. 


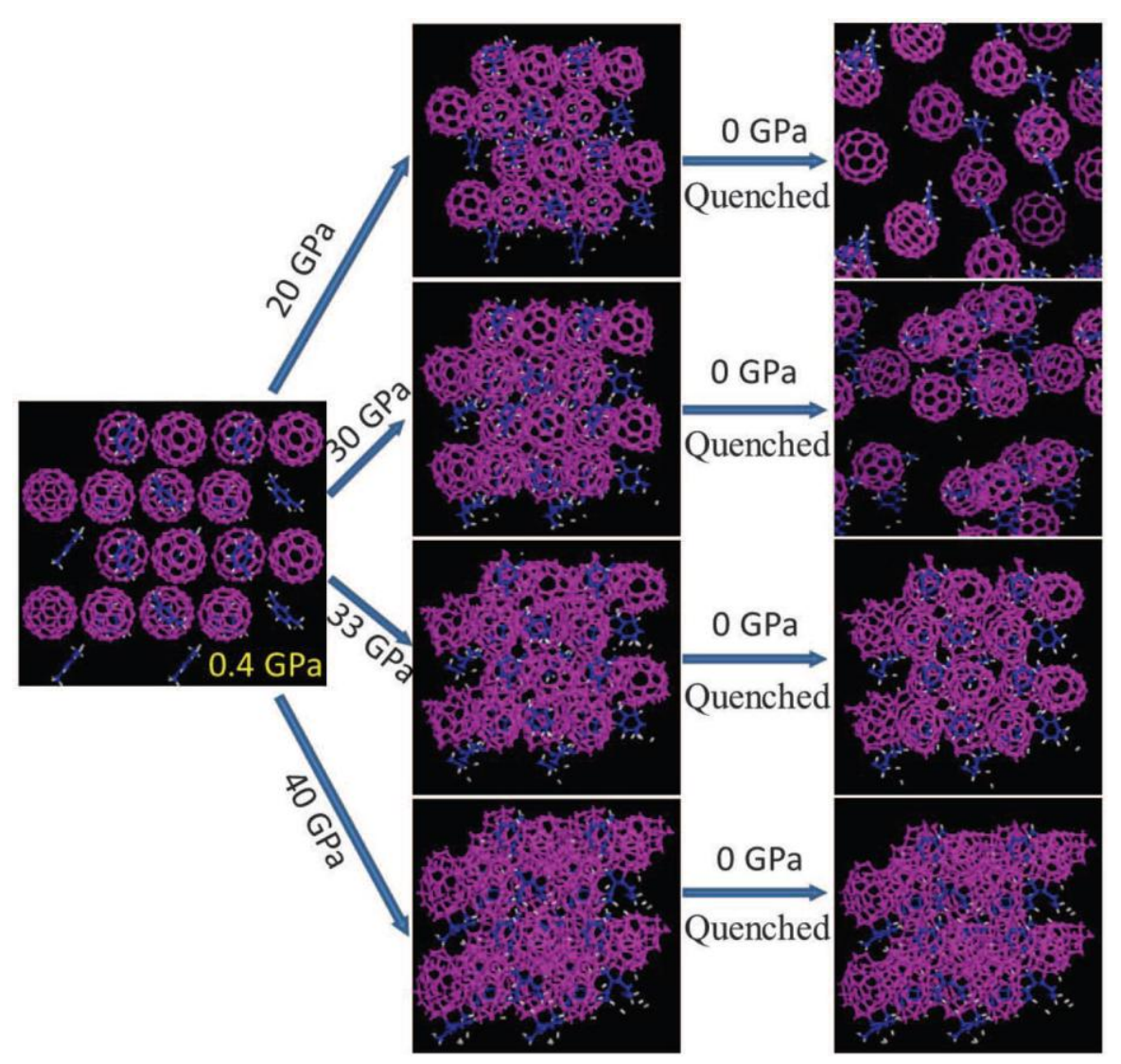

Figure 10.
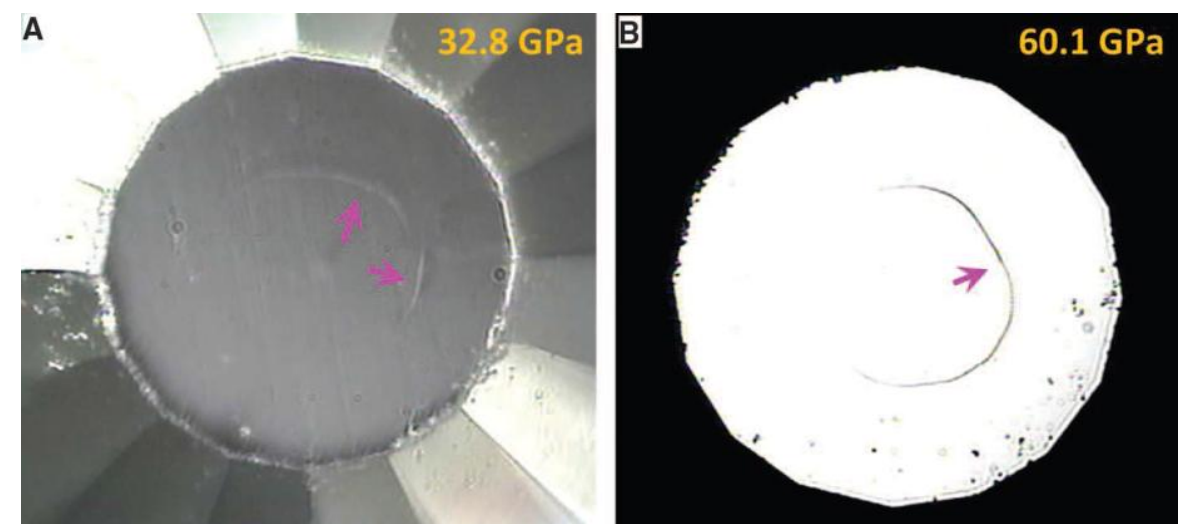

Figure 11. 
Table 1 . The solubility of $\mathrm{C}_{60}$ and $\mathrm{C}_{70}$ in some solvents. [91]

\begin{tabular}{|c|c|c|}
\hline Solvent & $\mathrm{C}_{60}$ & $\mathrm{C}_{70}$ \\
\hline 1-chloronaphthalene & $51 \mathrm{mg} / \mathrm{mL}$ & \\
\hline 1-methylnaphthalene & $33 \mathrm{mg} / \mathrm{mL}$ & \\
\hline 1,2-dichlorobenzene & $24 \mathrm{mg} / \mathrm{mL}$ & $36.2 \mathrm{mg} / \mathrm{mL}$ \\
\hline 1,2,4-trimethylbenzene & $18 \mathrm{mg} / \mathrm{mL}$ & \\
\hline tetrahydronaphthalene & $16 \mathrm{mg} / \mathrm{mL}$ & \\
\hline carbon disulfide & $8 \mathrm{mg} / \mathrm{mL}$ & $9.875 \mathrm{mg} / \mathrm{mL}$ \\
\hline 1,2,3-tribromopropane & $8 \mathrm{mg} / \mathrm{mL}$ & \\
\hline chlorobenzene & $7 \mathrm{mg} / \mathrm{mL}$ & \\
\hline xylene & $5 \mathrm{mg} / \mathrm{mL}$ & $3.985 \mathrm{mg} / \mathrm{mL}(\mathrm{p}$-xylene $)$ \\
\hline cumene & $4 \mathrm{mg} / \mathrm{mL}$ & \\
\hline toluene & $3 \mathrm{mg} / \mathrm{mL}$ & $1.406 \mathrm{mg} / \mathrm{mL}$ \\
\hline benzene & $1.5 \mathrm{mg} / \mathrm{mL}$ & $1.3 \mathrm{mg} / \mathrm{mL}$ \\
\hline carbon tetrachloride & $0.447 \mathrm{mg} / \mathrm{mL}$ & $0.121 \mathrm{mg} / \mathrm{mL}$ \\
\hline chloroform & $0.25 \mathrm{mg} / \mathrm{mL}$ & \\
\hline n-hexane & $0.046 \mathrm{mg} / \mathrm{mL}$ & $0.013 \mathrm{mg} / \mathrm{mL}$ \\
\hline acetonitrile & $0.004 \mathrm{mg} / \mathrm{mL}$ & \\
\hline methanol & $0.00004 \mathrm{mg} / \mathrm{mL}$ & \\
\hline pentane & $0.004 \mathrm{mg} / \mathrm{mL}$ & $0.002 \mathrm{mg} / \mathrm{mL}$ \\
\hline heptane & & $0.047 \mathrm{mg} / \mathrm{mL}$ \\
\hline octane & $0.025 \mathrm{mg} / \mathrm{mL}$ & $0.042 \mathrm{mg} / \mathrm{mL}$ \\
\hline decane & $0.070 \mathrm{mg} / \mathrm{mL}$ & $0.053 \mathrm{mg} / \mathrm{mL}$ \\
\hline dodecane & $0.091 \mathrm{mg} / \mathrm{mL}$ & $0.098 \mathrm{mg} / \mathrm{mL}$ \\
\hline acetone & & $0.0019 \mathrm{mg} / \mathrm{mL}$ \\
\hline isopropanol & & $0.0021 \mathrm{mg} / \mathrm{mL}$ \\
\hline dioxane & $0.0041 \mathrm{mg} / \mathrm{mL}$ & \\
\hline mesitylene & $0.997 \mathrm{mg} / \mathrm{mL}$ & $1.472 \mathrm{mg} / \mathrm{mL}$ \\
\hline dichloromethane & $0.254 \mathrm{mg} / \mathrm{mL}$ & $0.080 \mathrm{mg} / \mathrm{mL}$ \\
\hline
\end{tabular}


Table 2. Summary of information of most of reported fullerenes solvates.

\begin{tabular}{|c|c|c|c|c|}
\hline Solvate & Crystal structure & $\begin{array}{l}\text { Stability in } \\
\text { air at } \\
\text { ambient } \mathrm{T}\end{array}$ & $\begin{array}{l}\text { Characterization } \\
\text { technique used }\end{array}$ & references \\
\hline $\mathrm{C}_{60} * 1 m$-xylene & $\begin{array}{l}\text { Hcp, } \\
a=2.376 \mathrm{~nm}, \\
c=1.008 \mathrm{~nm}\end{array}$ & stable & $\begin{array}{l}\text { XRD, Raman, IR, } \\
\text { TGA, TEM, SEM }\end{array}$ & Ref. 28 \\
\hline $\mathrm{C}_{60} * 4 \mathrm{C}_{6} \mathrm{H}_{6}$ & hcp & & XRD, Raman & $\begin{array}{l}\text { Ref. } 31, \\
34,45,94\end{array}$ \\
\hline $\mathrm{C}_{60} * 10 \mathrm{CCl}_{4}$ & $\mathrm{Fcc} a=2.739 \mathrm{~nm}$ & stable & XRD & Ref. 95 \\
\hline $\mathrm{C}_{60} * \mathrm{C}_{6} \mathrm{H}_{5} \mathrm{CH}_{3}$ & monoclinic & Metastable & IR, Raman & \multirow{5}{*}{$\begin{array}{l}\text { Ref. 31, } \\
45\end{array}$} \\
\hline $\mathrm{C}_{60} * 0.5 \mathrm{C}_{6} \mathrm{H}_{5} \mathrm{CH}_{3}$ & & & IR & \\
\hline $\mathrm{C}_{60} *$ decalin & hcp & & IR & \\
\hline $\begin{array}{l}\mathrm{C}_{60} * 6 n \text {-decane } \\
(210 \square \mathrm{C})\end{array}$ & & & IR & \\
\hline $\begin{array}{l}\mathrm{C}_{60} * 3 n \text {-decane } \\
(340 \square \mathrm{C})\end{array}$ & & & IR & \\
\hline $\mathrm{Cf}_{60} * 2 \mathrm{CHBr}_{3}$ & $\begin{array}{ll}\text { Hcp, } & \mathrm{a}=1.0226 \\
\mathrm{~nm}, & \mathrm{c}=1.0207 \\
\mathrm{~nm} & \\
\end{array}$ & & XRD, TGA, NMR & Ref. 96 \\
\hline $\begin{array}{l}\mathrm{C}_{60} * 1,1,2 \text {-trichloroetha } \\
\text { ne }\end{array}$ & $\begin{array}{l}\text { Orthorhombic } \\
a=1.0164 \mathrm{~nm} \\
b=3.1390 \mathrm{~nm} \\
c=1.0130 \mathrm{~nm}\end{array}$ & Metastable & SEM, XRD, TGA & Ref. 27 \\
\hline $\mathrm{C}_{60} * n$-hexane & $\begin{array}{l}\text { Orthorhombic } \\
a=1.0249 \mathrm{~nm} \\
b=3.1308 \mathrm{~nm} \\
c=1.0164 \mathrm{~nm}\end{array}$ & stable & XRD, TGA, Raman & $\begin{array}{l}\text { Ref. } 31, \\
38\end{array}$ \\
\hline $\mathrm{C}_{60} * \mathrm{H}_{2} \mathrm{CCl}_{2}$ & $\begin{array}{l}\text { Cubic } \\
\mathrm{A}=2.3284 \mathrm{~nm}\end{array}$ & Unstable: & XRD, TGA & Ref. 97 \\
\hline $\mathrm{C}_{60} * 2$ Ferrocene & triclinic & & & Ref. 98 \\
\hline $\mathrm{C}_{60} * 12 \mathrm{BrCCl}_{3}$ & $\begin{array}{l}\text { Cubic } \\
\mathrm{A}=2.7591 \mathrm{~nm}\end{array}$ & Unstable & \multirow[t]{2}{*}{ XRD, TGA, SEM } & \multirow[t]{2}{*}{ Ref. 99} \\
\hline $\mathrm{C}_{60} * 2 \mathrm{BrCCl}_{3}$ & $\begin{array}{l}\text { Hexagonal } \\
a=1.016 \mathrm{~nm} \\
b=1.089 \mathrm{~nm}\end{array}$ & Stable & & \\
\hline $\mathrm{C}_{60} * 2 / 3 n$-nonane & $\begin{array}{l}\text { Orthorhombic } \\
a=1.010 \mathrm{~nm} \\
b=1.019 \mathrm{~nm}\end{array}$ & Stable & SEM, XRD, TGA & Ref. 100 \\
\hline
\end{tabular}




\begin{tabular}{|c|c|c|c|c|}
\hline & $\mathrm{c}=4.871 \mathrm{~nm}$ & & & \\
\hline $\mathrm{C}_{60} * 2\left(\mathrm{CH}_{3}\right) \mathrm{CCl}_{3}$ & monoclinic & & & Ref. 33 \\
\hline $\mathrm{C}_{60} * 2 \mathrm{C}_{6} \mathrm{H}_{5} \mathrm{CH}_{3}$ & Monoclinic & & \multirow{12}{*}{$\begin{array}{l}\text { XRD, Differential } \\
\text { scanning } \\
\text { calorimetry (DSC) }\end{array}$} & \multirow[t]{12}{*}{ Ref. 94} \\
\hline $\mathrm{C}_{60} * \mathrm{C}_{6} \mathrm{H}_{5} \mathrm{CH}_{3}$ & monoclinic & & & \\
\hline $\mathrm{C}_{60} * 2 \mathrm{C}_{6} \mathrm{H}_{5} \mathrm{I}$ & monoclinic & & & \\
\hline $\mathrm{C}_{60} * 3 m-\mathrm{C}_{6} \mathrm{H}_{4} \mathrm{Br}_{2}$ & monoclinic & & & \\
\hline $\mathrm{C}_{60} * 2 m-\mathrm{C}_{6} \mathrm{H}_{4} \mathrm{Br}_{2}$ & monoclinic & & & \\
\hline $\mathrm{C}_{60} * \mathrm{C}_{6} \mathrm{H}_{5} \mathrm{Cl}$ & monoclinic & & & \\
\hline $\mathrm{C}_{60} * 2 o$-xylene & monoclinic & & & \\
\hline $\mathrm{C}_{60} * 2 / 3 m-\mathrm{C}_{6} \mathrm{H}_{4} \mathrm{Br}_{2}$ & hexagonal & & & \\
\hline $\mathrm{C}_{60} * 2 / 3 m$-xylene & hexagonal & & & \\
\hline $\mathrm{C}_{60} * 2 / 3 m-\mathrm{C}_{6} \mathrm{H}_{4} \mathrm{Cl}_{2}$ & hexagonal & & & \\
\hline $\mathrm{C}_{60} * 2 / 3 \mathrm{C}_{6} \mathrm{H}_{3}\left(\mathrm{CH}_{3}\right)_{3}$ & hexagonal & & & \\
\hline $\mathrm{C}_{70} * 2 o$-xylene & triclinic & & & \\
\hline $\mathrm{C}_{70} *$ Ferrocene & $\begin{array}{l}\text { monoclinic } \\
a=2.938 \mathrm{~nm} \\
b=1.036 \mathrm{~nm} \\
c=2.021 \mathrm{~nm}\end{array}$ & & & Ref. 101 \\
\hline $\mathrm{C}_{70} * 2$ mesitylene & $\begin{array}{l}\text { Cubic } \\
\mathrm{a}=1.04774 \mathrm{~nm}\end{array}$ & stable & $\begin{array}{l}\text { XRD, TGA, SEM, } \\
\text { Fluorescence }\end{array}$ & Ref. 102 \\
\hline $\mathrm{C}_{60} * \mathrm{CS}_{2}$ & monoclinic & & NMR & $\begin{array}{l}\text { Ref. } 40, \\
41\end{array}$ \\
\hline $\mathrm{C}_{60} * \mathrm{C}_{8} \mathrm{H}_{8}$ & $\begin{array}{l}\text { Fcc } \\
\mathrm{a}=1.474 \mathrm{~nm}\end{array}$ & stable & $\begin{array}{l}\text { XRD, TEM, Raman, } \\
\text { IR, TGA, and Mass } \\
\text { spectrometry, NMR }\end{array}$ & Ref. 103 \\
\hline $\mathrm{C}_{70} * \mathrm{C}_{8} \mathrm{H}_{8}$ & $\begin{array}{l}\text { Tetragonal } \\
\text { (Room } \\
\text { Temperature) } \\
\text { I4/mmm } \\
\text { FCC (at >375K) }\end{array}$ & stable & $\begin{array}{l}\text { XRD, TEM, Raman, } \\
\text { IR, TGA, and Mass } \\
\text { spectrometry, NMR }\end{array}$ & $\begin{array}{l}\text { Ref. 103, } \\
104\end{array}$ \\
\hline $\mathrm{C}_{60} * \mathrm{~S}_{16}$ & $\begin{array}{l}\text { Monoclinic } \\
a=20.867(4) \AA, \\
b=21.062(4) \AA, \\
c=10.508(2) \AA, \\
\beta=111.25(7)^{\circ}\end{array}$ & stable & XRD, Raman & Ref. 105 \\
\hline $\mathrm{C}_{60} * \mathrm{n}$-pentane & orthorhombic & & XRD & Ref37 \\
\hline $\mathrm{C}_{60} *$ heptane & $\begin{array}{l}\text { Hexagonal } \\
\mathrm{a}=1.000(4) \mathrm{nm} \\
\mathrm{b}=1.016(1) \mathrm{nm}\end{array}$ & stable & XRD, TGA, SEM & Ref39 \\
\hline $\mathrm{C}_{60} * \mathrm{TDAE}$ & $\begin{array}{l}\text { Monoclinic } \\
\mathrm{a}=1.5849 \mathrm{~nm} \\
\mathrm{~b}=1.2987 \mathrm{~nm} \\
\mathrm{c}=0.9965 \mathrm{~nm}\end{array}$ & unstable & $\begin{array}{l}\text { XRD, Magnetic } \\
\text { measurement, } \\
\text { Electron } \\
\text { resonance }\end{array}$ & Ref. 55 \\
\hline
\end{tabular}




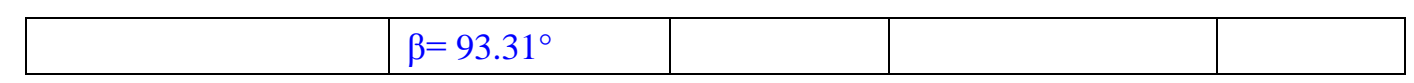

